\title{
SGD $\begin{gathered}\text { Sosyal Güvenlik Dergisi } \\ \text { Journal of Social Security }\end{gathered}$ \\ P-ISSN: 2146-4839 \\ E-ISSN: 2148-483X
}

\section{Bölgesel Kalkınma Perspektifinden İşgücü Hareketliliğinin Değerlendirilmesi: Dirençli Temel Bileşenleri Analizi Uygulaması}

\section{Assessing Labor Mobility in Regional Development: Application of Robust Principal Component Analysis}

\author{
Deniz KOÇAK
}

Osmaniye Korkut Ata Üniversitesi, İktisadi ve İdari Bilimler Fakültesi, Ekonometri Bölümü

\section{Yasin ERTÜRK}

Ankara Hacı Bayram Veli Üniversitesi, İktisadi ve İdari Bilimler Fakültesi, Maliye Bölümü

\section{Murat ATAN}

Ankara Hacı Bayram Veli Üniversitesi, İktisadi ve İdari Bilimler Fakültesi, Ekonometri Bölümü

\author{
Aralik 2020, Cilt 10, Say1 2, Sayfa 353-370 \\ December 2020, Volume 10, Issue 2, Page \\ 353-370 \\ P-ISSN: 2146-4839 \\ E-ISSN: 2148-483X
}

$2020-2$

e-posta: sgd@sgk.gov.tr

Yazılar yayınlanmak üzere kabul edildiği takdirde, SGD elektronik ortamda tam metin olarak yayımlamak da dahil olmak üzere, tüm yayın haklarına sahip olacaktır. Yayınlanan yazılardaki görüşlerin sorumluluğu yazarlarına aittir. Yazı ve tablolardan kaynak gösterilerek alıntı yapılabilir.

If the manuscripts are accepted to be published, the SGD has the possession of right of publicationand the copyright of the manuscripts, included publishing the whole text in the digital area. Articles published in the journal represent solely the views of the authors.

Some parts of the articles and the tables can be citeded by showing the source. 


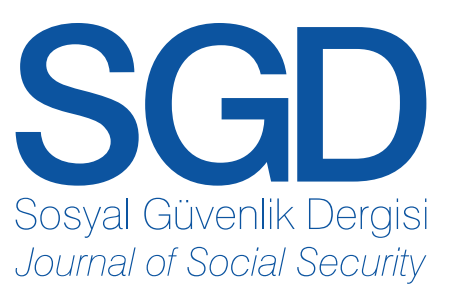

Cilt: 10 - Say1: 2 - Y11: 2020

Volume: 10 - Issue: 2 - Year: 2020

P-ISSN: 2146-4839

E-ISSN: 2148-483X

Sahibi / Owner of the Journal

Sosyal Güvenlik Kurumu Adına / On behalf of the Social Security Institution

İsmail YILMAZ

(Kurum Başkanı / President of the Institution)

Sorumlu Yazı İşleri Müdürü / Responsible Publication Manager

Uğur KORKMAZ

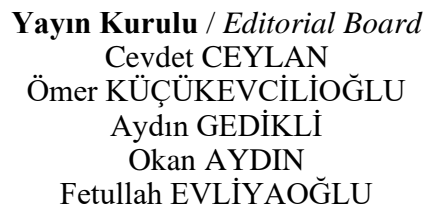

Editörler / Editors

Doç. Dr. Erdem CAM

Selda DEMİR

Redaksiyon / Redaction

Nihan ERTÜRK

Yayın Türü: Uluslararası Süreli Yayın / Type of Publication: International Periodical

Yayın Aralığı: 6 aylık / Frequency of Publication: Twice a Year

Dili: Türkçe ve İngilizce / Language: Turkish and English

Basım Tarihi / Press Date: 20.12.2020

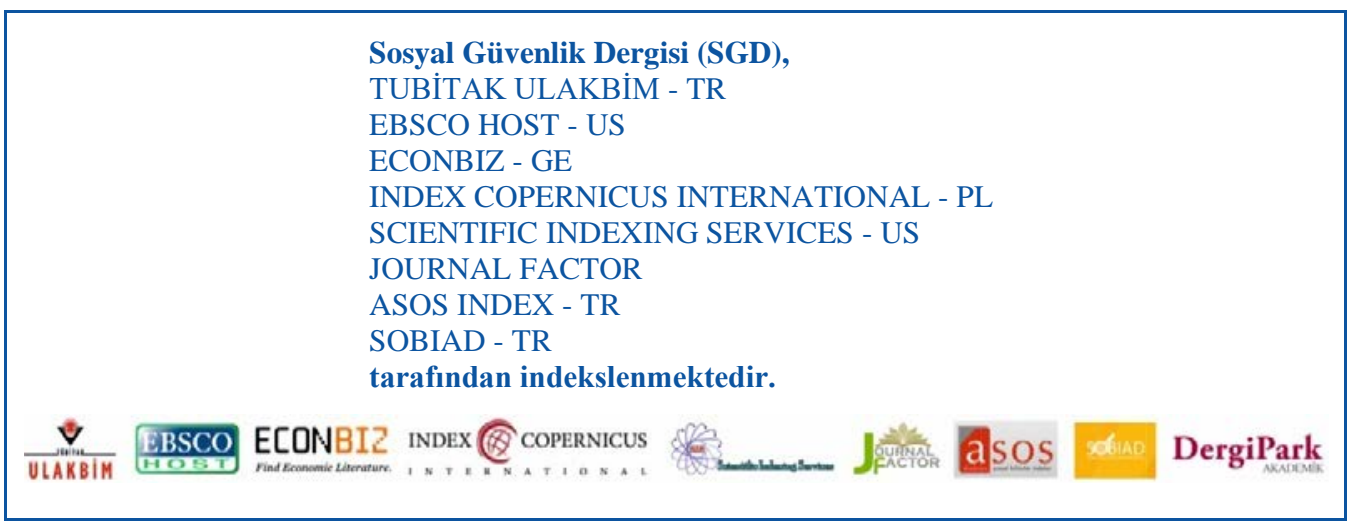

CTüm hakları saklıdır. Sosyal Güvenlik Dergisi’nde yer alan bilimsel çalışmaların bir kısmı ya da tamamı telif hakları saklı kalmak üzere eğitim, araştırma ve bilimsel amaçlarla çoğaltılabilir. Dergide yayımlanan makalelerdeki fikir ve görüşler Sosyal Güvenlik Kurumunun kurumsal görüşünü yansıtmaz, tüm görüşler yazarlarına aittir.

Tasarım / Design: PERSPEKTİF Matbaacılık Tasarım Tic.Ltd.Şti. (0 312) 3842055 - Ankara

Basım Yeri / Printed in: PERSPEKTİF Matbaacılık Tasarım Tic.Ltd.Şti. (0 312) 3842055 - Ankara

İletişim Bilgileri / Contact Information

Sosyal Güvenlik Kurumu Başkanlığı

Ziyabey Caddesi No: 6 Balgat / Ankara / TÜRKIYE

Tel / Phone: +90 3122078891 - 2078770 - Faks / Fax: +90 3122077819

Erişim/Webpage: http://www.sgk.gov.tr/wps/portal/sgk/sgd/tr - e-posta / e-mail: sgd@sgk.gov.tr 
Professor Yener ALTUNBAȘ

Bangor University - UK

Professor Paul Leonard GALLINA

Bishop’s University - CA

Professor Jacqueline S.ISMAEL

University of Calgary - CA
Professor Özay MEHMET

University of Carleton - CA

Professor Allan MOSCOVITCH

University of Carleton - CA

Professor Mark THOMPSON

University of British Columbia - CA
Asst. Prof. Sara HSU

State University of New York- USA

Asst. Prof. C. Rada Von ARNIM

University of Utah - USA

\section{ULUSAL DANIŞMA KURULU / NATIONAL ADVISORY BOARD}

Prof. Dr. Ahmet Cevat ACAR

İstanbul Üniversitesi

İşletme Fakültesi

Prof. Dr. İsmail AĞIRBAŞ

Ankara Üniversitesi

Sağlık Bilimleri Fakültesi

Prof. Dr. Levent AKIN

Ankara Üniversitesi

Hukuk Fakültesi

Prof. Dr. Yusuf ALPER

Bursa Uludağ Üniversitesi

İktisadi ve İdari Bilimler Fakültesi

Prof. Dr. Faruk ANDAÇ

Cağ Üniversitesi

Hukuk Fakültesi

Prof. Dr. Kadir ARICI

Ankara Hacı Bayram Veli Üniversitesi

Hukuk Fakültesi

Prof. Dr. Onur Ender ASLAN

Ankara Sosyal Bilimler Üniversitesi

Siyasal Bilgiler Fakültesi

Prof. Dr. Zakir AVŞAR

Ankara Hacı Bayram Veli Üniversitesi

İletișim Fakültesi

Prof. Dr. Ufuk AYDIN

İstanbul Aydın Üniversitesi

Hukuk Fakültesi

Prof. Dr. Abdurrahman AYHAN

Kıbris İlim Üniversitesi

Hukuk Fakültesi

Prof. Dr. Serpil AYTAÇ

Bursa Uludağ Üniversitesi

İktisadi ve İdari Bilimler Fakültesi

Prof. Dr. Mehmet BARCA

Ankara Sosyal Bilimler Üniversitesi

Siyasal Bilgiler Fakültesi

Prof. Dr. Süleyman BAŞTERZI

Ankara Üniversitesi

Hukuk Fakültesi

Prof. Dr. Nursen CANIKLİOĞLU

Marmara Üniversitesi

Hukuk Fakültesi

Prof. Dr. Fevzi DEMIR

Yaşar Üniversitesi

Hukuk Fakültesi
Prof. Dr. A. Murat DEMIRCİOĞLU

Yıldız Teknik Üniversitesi

Emekli Öğretim Üyesi

Prof. Dr. Ömer EKMEKÇI

İstanbul Üniversitesi

Hukuk Fakültesi

Prof. Dr. E. Murat ENGIN

Galatasaray Üniversitesi

Hukuk Fakültesi

Prof. Dr. Hediye ERGİN

Marmara Üniversitesi

İktisat Fakültesi

Prof. Dr. Şükran ERTÜRK

Dokuz Eylül Üniversitesi

Hukuk Fakültesi

Prof. Dr. Afsun Ezel ESATOĞLU

Ankara Üniversitesi

Sağlık Bilimleri Fakültesi

Prof. Dr. Ali GÜZEL

Kadir Has Üniversitesi

Hukuk Fakültesi

Prof. Dr. Alpay HEKIMLER

Tekirdağ Namık Kemal Üniversitesi

İktisadi ve İdari Bilimler Fakültesi

Prof. Dr. Oğuz KARADENIZ

Pamukkale Üniversitesi

İktisadi ve İdari Bilimler Fakültesi

Prof. Dr. Aşkın KESER

Bursa Uludağ Üniversitesi

İktisadi ve İdari Bilimler Fakültesi

Prof. Dr. Cem KILIC

TOBB Ekonomi ve Teknoloji Üniversitesi

İktisadi ve İdari Bilimler Fakültesi

Prof. Dr. Ali Riza OKUR

İstanbul Sabahattin Zaim Üniversitesi

Hukuk Fakültesi

Prof. Dr. Serdar SAYAN

TOBB Ekonomi ve Teknoloji Üniversitesi

İktisadi ve İdari Bilimler Fakültesi

Prof. Dr. Ali Nazım SÖZER

Yaşar Üniversitesi

Hukuk Fakültesi

Prof. Dr. Sarper SÜZEK

Atılım Üniversitesi

Hukuk Fakültesi
Prof. Dr. Müjdat SAKAR

Marmara Üniversitesi

İktisat Fakültesi

Prof. Dr. Savas TASKENT

İstanbul Teknik Üniversitesi

İşletme Fakültesi

Prof. Dr. Ferda YERDELEN TATOĞLU

İstanbul Üniversitesi

İktisat Fakültesi

Prof. Dr. Sabri TEKİR

İzmir Demokrasi Üniversitesi

İktisadi ve İdari Bilimler Fakültesi

Prof. Dr. Mehmet TOP

Hacettepe Üniversitesi

İktisadi ve İdari Bilimler Fakültesi

Prof. Dr. Türker TOPALHAN

Ankara Hacı Bayram Veli Üniversitesi

İktisadi ve İdari Bilimler Fakültesi

Prof. Dr. Aziz Can TUNCAY

Bahçeşehir Üniversitesi

Hukuk Fakültesi

Prof. Dr. M. Fatih USAN

Ankara Yıldırım Beyazıt Üniversitesi

Hukuk Fakültesi

Prof. Dr. Gülbiye YENIMAHALLELI

Ankara Üniversitesi

Sağlık Bilimleri Fakültesi

Doç. Dr. Gaye BAYCIK

Ankara Üniversitesi

Hukuk Fakültesi

Doc. Dr. Emel İSLAMOĞLU

Sakarya Üniversitesi

Siyasal Bilgiler Fakültesi

Doç. Dr. Saim OCAK

Marmara Üniversitesi

Hukuk Fakültesi

Doç. Dr. Ercüment ÖZKARACA

Marmara Üniversitesi

Hukuk Fakültesi

Doç. Dr. Sinem YILDIRIMALP

Sakarya Üniversitesi

Siyasal Bilgiler Fakültesi 
Prof. Dr. Levent AKIN

Ankara Üniversitesi

Hukuk Fakültesi

Prof. Dr. Yusuf ALPER

Bursa Uludağ Üniversitesi

İktisadi ve İdari Bilimler Fakültesi

Prof. Dr. Murat ATAN

Ankara Hacı Bayram Veli Üniversitesi

İktisadi ve İdari Bilimler Fakültesi

Prof. Dr. Sibel ATAN

Ankara Hacı Bayram Veli Üniversitesi

İktisadi ve İdari Bilimler Fakültesi

Prof. Dr. Şenay ÜÇDOĞRUK BİRECIKLII

Dokuz Eylül Üniversitesi

İktisadi ve İdari Bilimler Fakültesi

Prof. Dr. Nurşen CANIKLİĞGLU

Marmara Üniversitesi

Hukuk Fakültesi

Prof. Dr. Elif GÖKÇEARSLAN ÇİFTÇİ

Ankara Üniversitesi

Sağlık Bilimleri Fakültesi

Prof. Dr. Ömer EKMEKÇİ

İstanbul Üniversitesi

Hukuk Fakültesi

Prof. Dr. Zeki ERDUT

Dokuz Eylül Üniversitesi

İktisadi ve İdari Bilimler Fakültesi

Prof. Dr. Atilla GÖKÇE

Ankara Hacı Bayram Veli Üniversitesi

İktisadi ve İdari Bilimler Fakültesi

Prof. Dr. Banu UÇKAN HEKIMLER

Anadolu Üniversitesi

İktisadi ve İdari Bilimler Fakültesi

Prof. Dr. Cemal İYEM

Aydın Adnan Menderes Üniversitesi

Söke İşletme Fakültesi
Prof. Dr. İlknur KILKIS

Bursa Uludağ Üniversitesi

İktisadi ve İdari Bilimler Fakültesi

Prof. Dr. Handan KUMAŞ

Pamukkale Üniversitesi

İktisadi ve İdari Bilimler Fakültesi

Prof. Dr. Umut OMAY

İstanbul Üniversitesi

İktisat Fakültesi

Prof. Dr. Kamil ORHAN

Pamukkale Üniversitesi

İktisadi ve İdari Bilimler Fakültesi

Prof. Dr. Serap PALAZ

Bandırma Onyedi Eylül Üniversitesi

İktisadi ve İdari Bilimler Fakültesi

Prof. Dr. Faruk SAPANCALI

Dokuz Eylül Üniversitesi

İktisadi ve İdari Bilimler Fakültesi

Prof. Dr. Filiz Elmas SARAC

Ankara Hacı Bayram Veli Üniversitesi

İktisadi ve İdari Bilimler Fakültesi

Prof. Dr. Ferda YERDELEN TATOĞLU İstanbul Üniversitesi

İktisat Fakültesi

Prof. Dr. Aysen TOKOL

Bursa Uludağ Üniversitesi

İktisadi ve İdari Bilimler Fakültesi

Prof. Dr. Suat UĞUR

Çanakkale Onsekiz Mart Üniversitesi

Biga İktisadi ve İdari Bilimler Fakültesi

Prof. Dr. Handan YOLSAL

İstanbul Üniversitesi

İktisat Fakültesi

Doç. Dr. Erdem CAM

Ankara Üniversitesi

Siyasal Bilgiler Fakültesi
Doç. Dr. Hamdi EMEÇ

Dokuz Eylül Üniversitesi

İktisadi ve İdari Bilimler Fakültesi

Doç. Dr. Furkan EMIRMAHMUTOĞLU Ankara Hacı Bayram Veli Üniversitesi İktisadi ve İdari Bilimler Fakültesi

Doç. Dr. Aycan HEPSAĞ

İstanbul Üniversitesi

İktisat Fakültesi

Doç. Dr. Recep KAPAR

Muğla Sitkı Koçman Üniversitesi

İktisadi ve İdari Bilimler Fakültesi

Doç. Dr. Serdar KURT

Çanakkale Onsekiz Mart Üniversitesi

Biga İktisadi ve İdari Bilimler Fakültesi

Doç. Dr. Banu METİN

Ankara Hacı Bayram Veli Üniversitesi

İktisadi ve İdari Bilimler Fakültesi

Doç. Dr. Nagihan DURUSOY ÖZTEPE Pamukkale Üniversitesi

İktisadi ve İdari Bilimler Fakültesi

Doç. Dr. Ramazan ŞAHIN

Gazi Üniversitesi

Mühendislik Fakültesi

Doç. Dr. Özgür TOPKAYA

Çanakkale Onsekiz Mart Üniversitesi Biga İktisadi ve İdari Bilimler Fakültesi

Doç. Dr. Özlem YORULMAZ

İstanbul Üniversitesi

İktisat Fakültesi

Dr. Öğr. Üyesi Ömer DORU

Mardin Artuklu Üniversitesi

İktisadi ve İdari Bilimler Fakültesi

Dr. Öğr. Üyesi Özlem GÖKTAŞ

İstanbul Üniversitesi

İktisat Fakültesi

Dr. Cihan Serhat KART

Ankara Üniversitesi

Ayaş Meslek Yüksekokulu 


\section{SAYI DEĞERLENDİRME ISTATISSTIKLERİ}

EVALUATION STATISTICS FOR THIS ISSUE

Toplam gelen makale başvurusu

Yayına kabul edilen makale sayısı

Hakem süreci devam eden makale sayısı

Red edilen makale sayıs

Ön inceleme aşamasında red edilen makale sayısı

Makale kabul oranı
Number of received manuscript

39

Number of accepted manuscript

Under consideration

Rejected after evaluation

Rejected before evaluation

2

Accepted manuscript rate

$\% 35$ 
Araştırma Makalesi - Research Article

\section{Bölgesel Kalkınma Perspektifinden İşgücü Hareketliliğinin Değerlendirilmesi: Dirençli Temel Bileşenleri Analizi Uygulaması}

\section{Assessing Labor Mobility in Regional Development: Application of Robust Principal Component Analysis}

\author{
Deniz KOÇAK* \\ (iD) 0000-0002-5893-0564 \\ Yasin ERTÜRK ${ }^{* *}$ \\ (iD) 0000-0003-3809-2919 \\ Murat ATAN ${ }^{* * *}$ \\ (iD) 0000-0002-2485-9456
}

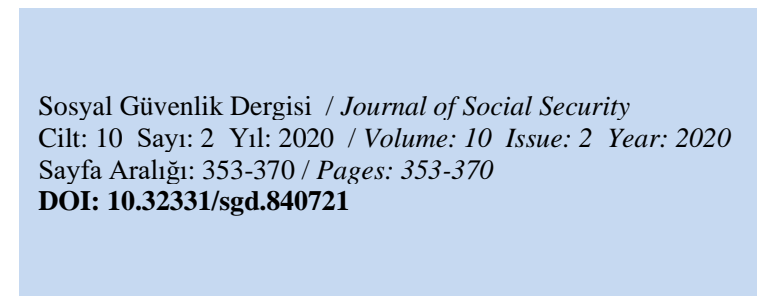

ÖZ

Bölgesel kalkınma hedeflerinin gerçekleştirilmesi gerekçesiyle bölgeler arası adaletsizliklerin giderilmesinde işgücü hareketliliği her zaman gündemde olan bir konu olmuştur. Türkiye'nin çeşitli bölgelerinde işgücü hareketliliğinin farklı olması, bölgeler arası adaletsizlikleri artırmaktadır. Nitekim ülkemizin çoğunlukla kıyı kesimlerinde yer alan illeri kapsayan bölgeleri, istihdam, işgücüne katılım gibi işgücü hareketliliğini temsil eden değişkenlerde oldukça yüksek değerlere sahip iken, doğu ve iç kesimlerde yer alan illeri kapsayan bölgelerinde bu durumun tam tersi şeklinde olduğu görülmektedir. Bölgesel kalkınma perspektifinden bu eşitsizliklerin üstesinden gelinmesi, bölgelerin işgücü hareketliliklerinin objektif bir şekilde değerlendirilmesi ile mümkün olmaktadır. Bu çalışmada Türkiye'nin İstatistiki Bölge Birimleri Sınıflandırması-2 (IBBBS-2) düzeyindeki 26 bölgesi ve bu bölgelerin işgücü hareketliliğiyle ilgili temel değişkenlere ait değerleri, dirençli temel bileşenler analizi (TBA) kapsamında kullanılmaktadır. 2014 -2018 arasındaki her y1 için tekrarlanan bu analiz sayesinde, bölgelerin ilgili yıllara göre işgücü hareketlilikleri karşılaştırmalı olarak değerlendirilmektedir. Çalışma sonucunda elde edilen bulgular göstermektedir ki, işgücü hareketliliğinin düşük olduğu bölgeler, kalkınmada geride kalan bölgelerdir. $\mathrm{Bu}$ bölgelerin işgücü hareketliliklerini artırıcı yönde uygulanacak olan politikalar ise bölgesel kalkınma hedeflerinin yakalanmasına katkı sağlayacaktır.

Anahtar Sözcükler: Bölgesel kalkınma, işgücü hareketliliği, İBBS-2, dirençli TBA

Önerilen atıf şekli: Koçak, D., Ertürk, Y. ve Atan, M. (2020). Bölgesel Kalkınma Perspektifinden İşüucü Hareketliliğinin Değerlendirilmesi: Dirençli Temel Bileşenleri Analizi Uygulaması. Sosyal Güvenlik Dergisi (Journal of Social Security). 10(2). 353-370

Geliş Tarihi/Received: 09/08/2020 • Güncelleme Tarihi/Revised: 07/10/2020 • Kabul Tarihi/Accepted: 16/12/2020

\footnotetext{
* Dr., Osmaniye Korkut Ata Üniversitesi, İktisadi ve İdari Bilimler Fakültesi, Ekonometri Bölümü, deniz.kocak@hbv.edu.tr

** Dr., Ankara Hacı Bayram Veli Üniversitesi, İktisadi ve İdari Bilimler Fakültesi, Maliye Bölümü, yasin.erturk@hbv.edu.tr

*** Prof. Dr., Ankara Hacı Bayram Veli Üniversitesi, İktisadi ve İdari Bilimler Fakültesi, Ekonometri Bölümü, murat.atan@hbv.edu.tr
} 


\section{GİRIŞ}

İşgücü hareketliliği, işgücü piyasasında sıklıkla gündeme getirilen bir konu olarak karşımıza çıkmaktadır. Bu kapsamda ülkedeki istihdam edilebilirliği, işgücüne katılım oranını, işsizliği doğrudan etkileyen işgücü hareketliliği, bölgesel kalkınma hedeflerinin gerçekleştirilmesinde de oldukça önemli bir rol oynamaktadır. Çünkü bölgeler arası işgücü piyasası çıktılarının eşitlenmesinde ya da gelir düzeylerinin yakınsamasında işgücü hareketliliği önemli bir itici güç olarak kabul edilmektedir. Diğer taraftan işgücü hareketliliği, günümüzde göç ile de ilişkilendirilmektedir. Bu kapsamda belirli bir bölge içinde ya da bölgeler arasında gerçekleşen işgücü hareketliliği, bireylerin ekonomik faydalarını en üst düzeye çıkarmaları amacıyla yer değiştirmelerini ifade etmektedir. Bu doğrultuda işgücü hareketliliğinin, kişi başına düşen gelir seviyesinin değişmesine neden olduğu da görülebilmektedir.

Günümüz Türkiye'sinde bölgeler arası gelişmişlik farklılıkları, önemli bir problem olarak çözüm beklemektedir. Ülkemizdeki ekonomik büyümenin bölgelere adaletli bir şekilde dağıtılması ve bu sayede bölgesel gelişmişlik farklılıklarının giderilmesinde, işgücü hareketliliğinin payı yadsınamazdır. Bölgesel düzeyde istihdamı artırıcı unsurların tespit edilmesi, piyasadaki ücret farklılıklarının giderilmesi, işsizliği azaltmayı hedefleyen politikaların hayata geçirilmesi gibi örnekler işgücü hareketliliğini temelden etkilemekte olan bölgesel gelişmişlik farklılıklarının azaltılmasını sağlamaktadır. Bu kapsamda bölgelerin işgücü hareketliliğinin rasyonel bir yöntem içerisinde değerlendirilmesi, ülkenin ekonomik gelişme yönünün ya da seviyesinin de doğru bir şekilde tespit edilmesini sağlamaktadır. Bu sayede geride kalan bölgelerin gelişmelerine yönelik yapılacak olan politika müdahaleleri, bölgeler arası adaletsizliklerin giderilebilmesine yardımcı olacaktır. Nitekim 1950'lerden itibaren ülkemizde uygulanan Beş Yıllık Kalkınma Planları ya da bölgesel projeler, bu amaçlarla uygulamaya konulmaktadır.

Yukarıda verilen bilgiler ışığında bu çalışmada, Türkiye'deki İBBS-2 düzeyindeki bölgelerin ekonomik büyüme ve bölgesel kalkınma hedefleri doğrultusunda işgücü hareketliliklerinin objektif bir şekilde değerlendirilmesi amaçlanmaktadır. Bölgelerin işgücü hareketliliklerini incelerken yıllara göre performans değişimlerine de yoğunlaşarak mevcut literatüre katkıda bulunulmaya çalışılmaktadır. Bu kapsamda çalışmanın birinci bölümünde, tarihsel süreç içerisinde bölgesel kalkınma kavramı, ikinci bölümünde ise bölgesel kalkınma perspektifinden işgücü hareketliliği açıklanmaktadır. Üçüncü bölümde, Türkiye'nin İBBS-2 düzeyindeki 26 bölgesinin işgücü hareketliliğinin değerlendirilmesinde yararlanılan dirençli temel bileşenler analizi (TBA) ve bu analizde kullanılan değişkenler detaylı olarak anlatılmaktadır. Çalışmanın dördüncü bölümünde, 2014-2018 yılları arsındaki her yıl için dirençli TBA'nın uygulanması neticesinde elde edilen bölgesel sonuçlar karşılaştırmalı olarak verilmektedir. Son bölümde ise bölgelerin işgücü hareketliliklerinin, kalkınmalarını ne düzeyde etkiledikleri konusunda elde edilen bulgular ve öneriler sunulmaktadır.

\section{I- BÖLGESEL KALKINMA}

\section{A- Bölgesel Kalkınma: Kavram ve Özellikler}

Bölge kavramı için çeşitli açılardan farklı tanımlamaların yapılması mümkündür. Ancak çalışmanın konusunu oluşturan bölge kavramı, iktisadi açıdan bölgeyi temsil etmektedir. $\mathrm{Bu}$ çerçevede bölge, ekonomik açıdan birbirine yakın birtakım özellikler gösteren mekânları olarak tanımlanabilmektedir (Sakal ve Demirhan, 2014: 182). Bununla birlikte bölge ve kalkınma kavramlarının bir araya gelerek oluşturduğu bölgesel kalkınma kavramı, özellikle küreselleşme süreci ile birlikte ülkelerin üzerinde önemle durdukları bir kavram olarak karşımıza çıkmaktadır. Bölgesel kalkınma kavramının daha net anlaşılması için, bölge 
kavramının yanında kalkınma kavramının da doğru bir şekilde tanımlanması yerinde olacaktır. Zira kalkınma kavramı çoğu zaman büyüme kavramı ile karıştırılmaktadır. Bu kapsamda kalkınma, ekonomik büyüme ve gelişme ile birlikte sosyal, siyasal ve idari anlamda gelişmeyi ifade eden üst bir kavram olarak tanımlanabilmektedir. Nitekim büyüme kavramı daha çok ekonomik anlamdaki gelişmeyi ifade etmektedir (Cankorkmaz, 2011: 116). Bu tanımlamalar özelinde bölgesel kalkınma kavramının, bir ülkede bölgeler arasında var olan gelişmişlik farkının çeşitli politikalar aracılığıyla en aza indirilmesi, başka bir ifade ile geri kalmış bölgelerdeki şartların iyileştirilmesi şeklinde tanımlanması mümkündür (Akın, 2006: 295). Diğer taraftan bölgesel kalkınma yalnızca ulusal boyutta düşünülmemesi gereken bir kavramdır. Çünkü ülkeler bölgesel kalkınma noktasında belirli bir seviyeye ulaştıkları zaman uluslararası rekabet içerisine girebileceklerdir.

\section{B- Bölgesel Kalkınmanın Amaçları}

Bölgesel kalkınma politikaları, ülkeler tarafından çeşitli amaçlar doğrultusunda uygulanmaktadır. $\mathrm{Bu}$ amaçların başında kırsal kesim ile kentleşme arasındaki dengenin sağlanması gelmektedir. En genel tabirle bölgeler arasındaki göç hareketlerinin geri kalmış bölgelerden, gelişmiş bölgelere doğru olduğu görülmektedir. Çünkü geri kalmış olan bölgeler birçok açıdan bireylerin ihtiyaçlarına cevap verememektedir. Bu nedenle gelişmiş olan bölgeler bireyler için cazibe merkezi haline gelmektedir (Sivri vd., 2000: 383). Bu durum bölgeler arası farklılıkların daha da artmasına ve adaletsiz yapının daha da derinleşmesine neden olmaktadır. Çünkü kontrolsüz bir şekilde gerçekleşen göç hareketleri kentlerin yapısını zorlamaya başlayarak, başta işsizlik olmak üzere çarpık yapılaşma kaçakçılık, altyapı sorunları ile eğitim ve sağlık hizmetlerinde birtakım sorunların yaşanmasına yol açmaktadır (Bozdoğan, 2014: 59). Ayrıca kentleşme sonucunda böyle bir sonucun ortaya çıkmasında, kırsal kesimde var olan şartların teknolojik gelişmeler ile birlikte değişerek insan odaklı yapının makineleşmeye doğru evrilmesi ile birlikte doğal afetler ve iklim koşulları sonucunda toprak verimliliğinin de azalmaktadır. Bununla birlikte kentlerde iş imkânlarının kırsal kesime göre daha fazla ve çeşitli olması bu durumun ortaya çıkmasındaki bir başka etken olarak görülmektedir (Keleş, 2000: 23-24).

Bölgesel kalkınma politikalarının temel amaçlarından bir tanesi de şüphesiz ki bölgeler arasındaki refah düzeyinin eşit düzeye getirilmesidir. Bu noktada yapılacak ilk iş, geri kalmış bölgelerdeki şartların iyileştirilmesi, gerek kamu gerekse özel sektör yatırımlarının bu bölgelerde yoğunlaştırılmasıdır. Ancak bu sayede söz konusu bölgeler büyüme hususunda ülke ekonomisine katkı sağlayacaktır. Aksi takdirde mevcut farklılıklar giderek derinleşecektir (Rösch, 1992: 1). Politika yapıcılar, bölgesel farklılıkların ortaya çıkardığı istihdam gibi önemli sorunları çözmek için birtakım çözümler geliştirmelidir. Bu da ancak bölgelerin mevcut yapılarının iyi bir şekilde analiz edilmesi ile mümkün olacaktır. Zira yalnızca bölgelerin güçlü yanlarının tespit edilmesi ile bölgesel kalkınma politikaları büyümeye pozitif yönde bir etki yapacaktır. Bu şekilde geri kalmış bölgelerin sorunlarının çözülmesi, bölgesel kalkınma hedeflerinin yakalanmasına ortam hazırlayacaktır. Ayrıca böyle bir politikanın izlenmesi bölgelerarası rekabetin gelişmesine de katkı sağlayacaktır. Bu gelişme ise başta ulusal ekonomik yapıya katkı sağlamakla birlikte uluslararası rekabet konusunda da pozitif bir etki oluşturacaktır (Şahinkaya, 2001: 682).

Bir ülkedeki bölgelerin her biri ekonomik, mali, sosyal ve kültürel açıdan oldukça farklı gelişmişlik düzeylerine sahiptir. Bölgesel kalkınma politikaları sayesinde gelişmiş bölgeler ile gelişmekte olan bölgeler arasındaki bu farklılıkların kapatılması son derece önemlidir. Çünkü bu farklılıkların kapatılmaması sonucunda gelişmiş olan bölgeler zaman içerisinde yaşam standardı ve koşulları açısından giderek daha çok cazip hale gelecek bunun sonucunda da geri kalmış bölgeler mevcut durumlarından daha kötü bir duruma gelecektir. Bu nedenle 
bölgesel kalkınma politikalarının amaçlarının en optimal seviyede yerine getirilmesi son derece önemlidir. Ancak bu şekilde ekonomik ve sosyal düalist yapının önüne geçilmesi mümkün olacaktır (Meyer, 1966: 376). Bu çerçevede yapılması gerekenlerin başında kişi başına düşen GSYH'nin özellikle geri kalmış bölgelerde artırılması gerekmektedir. Bununla birlikte eğitim ve sağlık hizmetleri başta olmak üzere kamusal mal ve hizmet sunumu dengeli bir şekilde gerçekleştirilmelidir. Bu sayede toplum yapısını etkileyecek olan negatif dışsallıkların da önüne geçilmiş olacaktır. Ayrıca çalışmanın da konusunu oluşturan iş gücü ve istihdama yönelik olumsuz şartların giderilmesi de bir başka önemli boyutu oluşturmaktadır (Bozdoğan, 2014: 61).

\section{C- Tarihsel Süreç İçerisinde Bölgesel Kalkınma Planları}

Bölgesel kalkınma ile ilgili olarak Türkiye'de diğer ülkelerde olduğu gibi içinde bulunulan dönemin şartlarına uygun ve öncelikli olarak ulusal çıkarlar gözetilerek birtakım politikalar uygulanmıştır. Bu çerçevede Cumhuriyetin ilk dönemlerindeki politikaların 1929 Büyük Buhran'ından etkilendiği görülmektedir. Bu dönemde devletçilik ve sanayileşme, bölgesel kalkınma politikalarına temel oluşturmuştur (Özaslan ve Ünlü, 2015: 69). 1960'lı yıllara gelindiğinde, ekonomide planlı döneme geçildiği ve bölgesel kalkınmada da doğal olarak bu süreçten etkilenildiği görülmektedir. Planlı dönemde ilk kalkınma planında, bölge planlama ve kalkınma adı altında bir başlık oluşturulmuştur. Bu kapsamda önceki dönemde olduğu gibi sanayileşme temele alınarak bunun yanında turizm ve tarımın geliştirilmesine yönelik politikalara da önem verilmiştir. Ayrıca önceki dönemden farklı olarak devlet desteği ve teşviklerinden ziyade, özel kesim yatırımları da bölgesel kalkınma hedefleri doğrultusunda sisteme dâhil edilmeye çalışılmıştır (Sezgin, 2013: 23). İkinci kalkınma planında, kamu yatırımları ile ilgili olarak geri kalmış bölgeler özelinde bir planlamaya gidilmiştir. Bu çerçevede ilgili bölgelerde yaşayan insanların hayat standartlarının yükseltilmesi hedeflenmiştir. Bununla birlikte şehirleşme hedefleri doğrultusunda altyapı yatırımlarına da önem verilmiştir. Ayrıca ikinci kalkınma planında sanayileşme, önceki dönemlerde olduğu gibi önemini korumaya devam etmiştir. Tüm bu hedefler doğrultusunda kamu yatırımlarının yetersiz kalabileceği düşüncesi ile özel sektör yatırımları çeşitli teşvik araçları ile desteklenerek sisteme dâhil edilmeye çalışılmıştır.

1973 - 1977 yıllarını kapsayan üçüncü kalkınma planında ise öncekilerden farklı olarak bölgesel düzeyden ziyade ulusal düzeyde bir politika tercihi yapıldığı görülmektedir. Bunun nedeni bölgesel anlamda uygulanan politikaların bölgeler arası adaletsizliği daha da artıracağı düşüncesinin hâkim olmasıdır. Üçüncü kalkınma planı ile ilgili olarak üzerinde durulması gereken önemli konulardan biri de Kalkınmada Öncelikli Yöreler projesi ya da kısaca ifade edilen KÖY projesidir (Özdemir, 2014: 15-17).

1979 - 1983 dönemini kapsayan dördüncü kalkınma planında, uygulanan ilk üç planın başarısızlığı ve istenilen sonuçların elde edilemediği üzerinde durularak bu çerçevede bir plan oluşturulmuştur. Söz konusu planın önemli özelliklerinden biri de Güneydoğu Anadolu Projesinin (GAP) ilk olarak bu dönemde gündeme getirilmesidir. Ayrıca bu planda ödemeler dengesi açıklarının giderilmesi üzerinde durularak bu çerçevede politikalar üretme gayreti içerisine girilmiştir (Takım, 2011: 157).

1985 - 1989 döneminde uygulanan beşinci kalkınma planının, ilk dört planın amaç ve hedeflerine benzer şekilde oluşturulduğu görülmektedir. $\mathrm{Bu}$ planda bölgeler arası adaletsizliklerin giderilmesi noktasında yapılması gerekenler konusunda detaylı bir envanter çalışması yapılarak Bölge Gelişme Şemaları oluşturulmuştur.

Altıncı kalkınma planı 1990 - 1994 dönemini kapsamaktadır. Bu kalkınma planında, özellikle gelişmiş bölgelerdeki nüfus ve sanayi yoğunluğunun azaltılması amaçlanmıştır. Ayrıca 
bölgelerin kendi içinde ve bölgeler arası göçlerin kontrolü üzerinde durulmuştur. $\mathrm{Bu}$ hedeflerin gerçekleştirilmesi adına geri kalmış bölgelerdeki mevcut şartların iyileştirilmesi amaçlanmıştır. Aksi takdirde istenilen sonuçlara ulaşılmasının mümkün olmayacağı görülmektedir. Bu kapsamda Fonksiyonel Bölge Projesi çerçevesinde 16 fonksiyonel bölge oluşturulmuştur. Ancak bu uygulama, daha sonraki kalkınma planlarında göz ardı edilmiştir ki bu nedenle istenilen sonuçlar elde edilememiştir. Başka bir ifade ile fonksiyonel bölge uygulaması bölgesel kalkınma sürecinde başarısız bir uygulama olarak karşımıza çıkmaktadır. Diğer taraftan bu dönemin önemli özelliklerinden biri de Küçük ve Orta Ölçekli Sanayiyi Geliştirme ve Destekleme İdaresi Başkanlığının (KOSGEB) kurulması olmuştur.

1996 - 2000 dönemini kapsayan yedinci kalkınma planında, KÖY’lerin ihtiyaçları giderilerek, mevcut standartların iyileştirilmesi gerekliliği üzerinde durulmuştur. Böylece bölgeler arası sosyo-ekonomik açıdan gelişmişlik farklılıklarının en aza indirgenebileceği vurgulanmıştır. Güneydoğu Anadolu Bölgesi'ni temel alan bu kalkınma planında sürdürülebilir kalkınmaya dikkat çekilmiş ve bu çerçevede politika oluşturma gayreti içerisine girilmiştir. Ayrıca sanayileşme ile birlikte tarım ve hayvancılıkta da modernizasyon çalışmaları desteklenmiştir. Söz konusu kalkınma planının bir diğer önemli özelliği ise yerel yönetimlerin bölgesel kalkınma konusunda daha aktif rol almaya başlaması olmuştur. Böylelikle gerek merkezi yönetim gerekse yerel yönetimlerin katkısı ile katma değeri yüksek ürünlerin elde edilmesi amaçlanmıştır.

2001 - 2005 dönemini kapsayan sekizinci kalkınma planı, Avrupa Birliği (AB) uyum süreci ile ilgili olarak bölgesel kalkınmanın daha farklı ve daha önemli bir politikaya dönüştüğü dönem olmuştur. $\mathrm{Bu}$ dönemde ulusal politikalar ile birlikte uluslararası politikaların uyumlaştırılması amaçlanmıştır. Sekizinci kalkınma planı ulusal düzeyde gelişmişlik farklılıklarının giderilerek uluslararası düzeyde rekabet edilebilir yapının kurulmasını hedeflemiştir. Ayrıca söz konusu kalkınma planı incelendiğinde, yaşam şartlarının iyileştirilmesi, fırsat eşitliğinin sağlanması gibi önemli konulara yer verildiği görülmektedir. Beş yıllık sürelerle hazırlanan kalkınma planları $\mathrm{AB}$ ile müzakerelerin başlaması ile beraber farklı bir boyut kazanmıştır. Bu çerçevede beş yıl süreli sekiz kalkınma planından sonra 2004 - 2006 döneminde ön ulusal kalkınma planı oluşturulmuştur. Bu plan çerçevesinde bölgesel kalkınma politikalarının aktif, katılımcı ve finansman sorunu yaşanmadan gerçekleştirilebilmesi için gerekli altyapının kurulması amaçlanmıştır. Ayrıca göç konusuna dikkat çekilmiş ve göç hareketlerinin bölgesel kalkınmaya zarar vermemesi için kontrol altında tutulması belirtilmiştir. Ayrıca bölgelere ilişkin verilerin AB'ye ait verilerle karşılaştırılarak durum değerlendirmesi yapılması adına İstatistiki Bölge Birimleri Sınıflandırılması (İBBS), 2002 yılında üç düzey olarak yapılmıştır. Bu kalkınma planının üzerinde durduğu önemli konulardan birisi de yatırım noktasında özel sektörün de sistem içerisinde aktif bir rol alabilmesinin sağlanması ve istihdam sorununun çözülmesi gerekliliği olmuştur. Söz konusu plan, bölgesel kalkınma hedeflerine ulaşılabilmesi için kamu kesimi, özel kesim ve sivil toplum kuruluşlarının koordineli bir biçimde çalışması gerektiğini ortaya koymuştur. Bu kapsamda kalkınma ajanslarının önemine dikkat çekilmiş ve 2006 yılında Kalkınma Ajanslarının Kuruluşu, Koordinasyonu ve Görevleri Hakkında Kanun yürürlüğe girmiştir. Plan incelendiğinde yerel yönetimlerin bölgesel kalkınma konusunda etkin bir rol üstlenmesine ve yerel yönetimlerin kaynak ihtiyaçlarının karşılanmasına vurgu yapılmıştır (Sakal ve Demirhan, 2014: 192-201). Bölgesel kalkınma politikaları ile ilgili geçirilen süreç incelendiğinde, kalkınma ajanslarına ayrı bir parantez açmak yerinde olacaktır. Bu çerçevede bölgesel kalkınma ajansları için farklı tanımlamalar yapılmakla birlikte, bu kalkınma ajanslarının hükümetten bağımsız olarak, belirli bir bölgenin çeşitli açılardan standartlarını yükseltme amacıyla kurulan ajanslar olarak tanımlanması mümkündür (Berber ve Çelepçi, 2005: 146). Diğer taraftan kalkınma ajanslarının birincil amacı, bölgedeki mevcut yapıyı 
analiz ederek ekonomiyi canlandırmaktır. Bununla birlikte uzun vadede bölgenin yatırım cazibesini artırarak ilgili bölgenin sosyo-ekonomik açıdan gelişmesine de katkı sağlamaktadır (Hasanoğlu ve Aliyev, 2006: 90).

Türkiye'de bölgesel kalkınma süreci 2007 - 2013 yılları arasında uygulanan dokuzuncu kalkınma planında da ele alınmıştır. İlgili kalkınma planı incelendiğinde, küreselleşme sürecinin bölgesel kalkınma politikalarına olan etkisi göze çarpmaktadır. Bu kalkınma planı öncelikle olarak rekabet gücünün artırılması ile birlikte istihdamın artırılması, beşeri gelişme ve sosyal dayanışmanın güçlendirilmesi, bölgesel gelişmenin sağlanması ile kamu hizmetlerinde kalitenin artırılmasını amaçlamıştır. Dokuzuncu kalkınma planı ile bölgesel kalkınma sürecinin önceki kalkınma planlarından farklı olarak daha sistematik bir yapıya kavuşturulduğunu ifade etmek yanlış olmayacaktır. Bu kalkınma planında özelikle AB bölgesel politikaları temel alınmıştır.

2014 - 2018 dönemini kapsayan onuncu kalkınma planı, özellikle 2023 hedefleri doğrultusunda önemli bir yere sahiptir. Bu kalkınma planı öncekilerden farklı olarak bölgesel kalkınmanın yanı sıra bölgesel rekabet edilebilirlik kavramını esas alarak oluşturulmuş olup, özelikle yüksek tutarlı kamu yatırımlarının az gelişmiş bölgelere yapılmasını ve buradaki şartların iyileştirilmesini hedeflemiştir. Bu çerçevede ilgili kalkınma planı incelendiğinde yaşanabilir mekân ve sürdürülebilir çevre hedefleri karşımıza çıkmaktadır. Buna bağlı olarak kalkınma ajanslarının daha aktif bir yapıya bürünmesi, uluslararası rekabet dikkate alındığında güçlü organize sanayi bölgelerinin oluşturulması gerekmektedir. Tüm bu hedefler kapsamında, kalkınma planları genel olarak değerlendirildiğinde onuncu kalkınma planının en kapsamlı kalkınma planı olduğunu ifade etmek mümkündür (Sakal ve Demirhan, 2014: 203-204).

\section{II- İŞGÜCÜ VE BÖLGESEL KALKINMA İLISŞKISII}

İşgücü piyasaları, ekonomik ve mali anlamda önemli bir alanı teşkil etmektedir. Bu kapsamda işgücü piyasaları ile ilgili olarak üzerinde durulması gereken temel konuların başında, istihdam ve işgücü hareketliliği gelmektedir. Bilindiği üzere bu iki kavram bireysel açıdan insan hayatında, toplumsal açıdan ise toplum yapısındaki temel ilişkilerde yer almaktadır. Bu nedenle ilgili kavramlara ilişkin usul ve esaslar, yasalarla korunma altına alınmıştır. İstihdam ve işgücü hareketliliğinde izlenen politikalar, ülke ekonomilerini doğrudan etkileyeceği için politika yapıcıların karar vermelerinden önce mevcut duruma ve ulaşılması amaçlanan hedeflere yönelik iyi bir analiz yapmaları gerekmektedir. Aksi takdirde istenilen sonuçların yakalanabilmesi pek mümkün olmayacaktır (Tansel, 2012: 19). İşgücü piyasası kavramını niteliği itibariyle ele alındığında, bazı kaynaklarda emek piyasası olarak da ifade edildiği görülmektedir. Bu çerçevede iş gücü piyasası ya da diğer ismi ile emek piyasası için, emeğin arz ve talep tarafında yer alanları bir noktada buluşturan, bununla birlikte emeğin fiyatı ile bu fiyat üzerinden ne ölçüde emek arzı yapılacağının belirlendiği piyasa olarak bir tanımlama yapılması mümkündür (Cerev ve Yenihan, 2017: 78).

Emek arzı ve emek talebi, işgücü piyasasının iki temel ayağını oluşturmaktadır. Ancak işgücü ile ilgili olarak bu iki kavramdan emek arzı emek talebine kıyasla öne çıkmaktadır. Emek arzı kavramı, kısaca emek piyasasında sunulan emek miktarı olarak tanımlanabilmektedir. Bununla birlikte farklı ücret düzeylerinde işçilerin yapmayı kabul ettikleri süre ya da miktar olarak da bir tanımlama yapılabilmektedir (Işş̆ıçok, 2011:2). İşgücü ile ilgili olarak üzerinde durulması gereken kavramlardan bir tanesi de nüfus kavramıdır. Bilindiği üzere nüfus, belli bir bölgede yaşayan insan topluluğunu ifade etmektedir. Nüfus, işgücü açısından önemli olmakla birlikte burada çalışma çağındaki nüfusa değinmek de yerinde olacaktır. Bireyin çalışma çağındaki nüfus içerisinde değerlendirilebilmesi için belli bir yaş sınırında olması 
gerekmektedir. $\mathrm{Bu}$ kapsamda genellikle zorunlu eğitim süresinin bittiği yıl alt sınırı oluşturmakta iken emeklilik yaşı üst sınırı oluşturmaktadır (Işı̆̆ıçok, 2011: 21). Bu yaş sınırlarının her ülkede kendi şartları içerisinde değişiklik göstermesi mümkündür. Ancak literatürde genel kabul gören aralık 15 - 64 yaş aralığg olarak belirlenmiştir (Cerev ve Yenihan, 2017: 79). Çalışma çağındaki nüfusla ilgili olarak bağımlılık oranı kavramının da bilinmesi yerinde olacaktır. Zira bu kavram çalışma çağındaki nüfus ile doğrudan ilişkilidir. $\mathrm{Bu}$ kapsamda bağımlılık oranı, çalışma çağındaki nüfusa bağımlı olan kişilerin oransal karşılığını ifade etmektedir (Gündoğan ve Biçerli, 2003: 10).

İşgücü piyasalarında efektif bir yapının oluşturulması, ekonomik gelişme kadar toplumsal gelişme açısından da önemlidir. Bölgesel kalkınma hedeflerinin gerçekleştirilebilmesi için işgücü piyasalarının mümkün olan en verimli seviyede kullanılması gerekmektedir. Aksi takdirde istihdam sorunları meydana gelecek, bu durum da bölgesel kalkınma hedeflerine ulaşılmasında engel teşkil edecektir. Bölgesel kalkınma hedeflerine birtakım politika araçları ile ulaşılabilmektedir. Bu araçlardan birisi bölgesel işgücüdür. Bölgesel işgücü konusunda etkin bir sistemin kurulması refah seviyesini olumlu etkileyecek olup, bunun da ülke ekonomisine pozitif yönde bir katkısı olacaktır. Bu kapsamda bölgesel işgücü verilerinin iyi bir şekilde analiz edilmesi şarttır. Çünkü ancak bu şekilde doğru politikalar uygulanabilmektedir. Aksi yönde yapılan uygulamalar istihdam sorununun çözülmesine katk1 sağlamayacaktır (Lordoğlu vd, 1999: 43).

İşücü hareketliliği, kişilerin yeni ekonomik imkân ve olanaklardan yararlanma kolaylılığı şeklinde tanımlanabilir. İşgücü hareketliliği, ekonomiler içinde birkaç farklı perspektifte olabilir. Göçe bağlı olarak veya coğrafi, mesleki ve eğitime bağlı olarak bölgeler arası işgücü hareketliliği olabilir. Walras'ın neo-klasik işgücü hareketliliği kavramına göre; ilk görüş işgücü bir tür sermayedir ve işgücü ücretin en yüksek olduğu bölgede çalışmayı ister. Bu yaklaşım neo-klasik mikro-ekonomik yaklaşım olarak nitelendirilir. İkinci görüşte ise; işgücü potansiyel olarak hizmet üreticisi olarak ele alınır ve işgücü işverenin karını en yüksek yapacağı bölgeye çağrılır. Bu yaklaşım ise makro-ekonomik modelleme yaklaşımı olarak adlandırılır. İşgücü hareketliliği mikro-ekonomik ve makro-ekonomik modellerin ekonomik dengeye ulaşmasını sağlamasında aracılık yapmaktadır. Ekonomik açıdan en iyileşmenin ön koşulu işgücü hareketliliğinin serbest olmasıdır. Ancak Lösch Walras'ın savunduğu "ücretlerin esnekliği” ilkesini benimsemekte birlikte ancak işgücü hareketliliğiyle bölgelerarası ücret farklılıklarının ortadan kalkacağını iddia etmektedir (Walras, 1953).

Nüfus ve kaynaklar arasındaki denge ilişkisini inceleyen nüfus ekonomisi kuramının temelinde en iyi (optimum) nüfus kavramı vardır. Buna göre varsayılan sabit kaynaklara göre nüfus kişi başına düşen reel geliri en büyükleyecek şekilde hareket eder. Her bölgenin nüfusu en iyi düzeyin üstünde veya altında olabilir. Eğer nüfus en iyi düzeyin altında ise yeni işgücünün marjinal verimliliği ve bölgesel refah artmakta buna karşın nüfus en iyi düzeyin üstünde ise aynı sonucun olması için bölgeden dışarıya belli sayıda işgücünün çıkması gereklidir. Burada tartışmalı olan kavram en iyi (optimum) nüfus kavramıdır. Şikago okulunun yaklaşımına göre neo-klasik işgücü hareketliliği yatırım kavramının mikroekonomik uzantısı olarak ele alınmaktadır. Yani göçmen işçi yapacağı yatırımın kârlılığını göz önüne almaktadır ve bu davranışta gelirin artması önemli olmaktadır. Bölgeler arası göç olgusu bu bireysel kârlılığın artıp artmayacağına bağlı olmaktadır. Kuznets ise mikroekonomik modelden makro-ekonomik modele geçişi önermektedir. Buna göre bölgesel göçte bireyin elde edeceği kârlılıktan çok makro düzeyde bölgesel kârlılık ön planda yer almaktadır. İşgücü hareketliliğinin temel amacı, bölgelerarası ve kesimler arası yapısal dengesizliklerin giderilmesi ve dengenin sağlanmasıdır. Bu çalışmada kullanılan net göç değişkeni ile yukarıda bahsedilen kuramsal ilişkiler modellenmiştir. 


\section{III- MATERYAL VE METOT}

Çalışmanın bu bölümünde, İBBS-2 düzeyindeki 26 bölgenin işgücü hareketliliğinin değerlendirilmesinde kullanılan yöntem ve veri setine yer verilmektedir. Bu kapsamda çalışmanın III-A- bölümünde dirençli temel bileşenler analizi detaylı olarak anlatılmaktadır. Diğer taraftan çalışmanın III-B- bölümünde ise IBBS-2 düzeyindeki bölgelerin işgücü hareketliliğinin değerlendirilmesinde kullanılan değişkenler sunulmaktadır.

Çalışmada temel amaç 2014 - 2018 dönemleri içinde nüfus ekonomisi kuramı çerçevesinde bölge için optimum nüfus kavramı üzerinde etkili olan net göç değişkeni ile neo-klasik işgücü hareketliliği kavramı çerçevesinde bölgede işgücü hareketliliğinin belirleyicisi olabilecek olan ve bölgede yapılacak olan yatırımlar ile oluşacak ücret ve fiyat dengelerinin işgücü piyasası üzerinde yansımasını gösterecek olan istihdam, işgücü ve işsizlik ile ilgili değişkenleri ve yatırımları temsilen bölgesel GSYH değişkenini kullanarak bölgelerin sıralamasını yapabilmek ve bu sıralamalar için yukarıda sayılan değişkenlerin ne derece de ayırımcı ve katkı sağlayıcı olabileceğini belirleyebilmek için çok değişkenli istatistik yöntemlerinden temel bileşenler analizi tercih edilmiştir. Ancak çalışmada değişkenlerin aykırı değerler içirmesi ve normal dağılım göstermemesi nedeniyle daha iyi ayırım sağlayan dirençli temel bileşen yaklaşımı kullanılmıştır.

\section{A- Dirençli Temel Bileşenler Analizi}

Klasik TBA, çok değişkenden oluşan veri setinde boyut indirgenmesi amacıyla sıklıkla kullanılan istatistiksel bir araçtır (Candès vd., 2011). Boyut indirgenmesi, aralarında korelasyon olan değişkenlerdeki maksimum varyansı açıklayan yeni bileşenlerin tespit edilmesiyle gerçekleştirilmektedir. Aralarında korelasyon olmayan bu yeni bileşenler, "temel bileșenler" adını almaktadır. Aynı zamanda bu yeni bileşenler, orijinal değişkenlerin doğrusal bileşenleri olmakla birlikte sayı olarak orijinal değişkenlerden daha azdır (Azadeh, Ghaderi ve Ebrahimipour, 2007).

Klasik temel bileşenler analizi, veri setinde aykırı değerlerin varlığı ya da verilerin normal dağılım göstermemesi gibi durumlarda tahmin geçerliliğini (istatistiksel anlamlılığını) yitirebilir (Huber ve Ronchetti, 1981; Feng vd., 2013). Bu sorunların üstesinden gelmek amacıyla, klasik TBA'nın sağlamlaştırılmasına yönelik alan yazında pek çok araştırma yapılmıştır. Bu kapsamda Campbell (1980), Li ve Chen (1985), De la Torre ve Black (2001), Wright vd. (2009), Xu vd. (2010), Candès vd. (2011) gibi çalışmalarda klasik TBA'da karşılaşılan sorunlar giderilmeye çalışılarak dirençli TBA yaklaşımları alan yazına kazandırılmıştır. Bu farklı yaklaşımlarda, aykırı değerlerin etkisini ortadan kaldıracak şekildeki kovaryans ya da korelasyon matrisinin kullanımı ile özvektörlerin hesaplanması mümkün olmakla birlikte projeksiyon izleme yaklaşımıyla da dirençli TBA'nın yapılması mümkündür (Campbell, 1980; Croux ve Haesbroeck, 2000; Croux ve Ruiz-Gazen, 2005).

$k$ sayıda birim ve $p$ sayıda değişkenden oluşan $k \times p$ boyutlu $X=\left(x_{1} \ldots x_{p}\right)_{k \times p}$ veri matrisindeki değişkenlerin doğrusal bileşenleri, kovaryans matrisinin veya korelasyon matrisinin özdeğerlerinin ve özvektörlerinin kullanımıyla hesaplanmaktadır. Bu veri matrisinde $x_{i j}$ terimi, $i$. birimin ve $j$. değişkene göre almış olduğu değeri ifade etmektedir, dolayısıyla $x_{m}=\left(x_{1 m} \ldots x_{k m}\right)^{T}, m=1,2, \ldots, p$ 'dir. Dirençli TBA'da analize başlamadan önce değişkenler arasındaki farklılığın giderilmesi amacıyla uygun bir ön işleme prosedürünün uygulanması gerekmektedir. $Z$ - skor normalleştirme, medyan merkezileştirme, min - maks normalizasyonu gibi dönüşümler ile ön işleme presedürü gerçekleştirilebilmektedir (Singh ve Singh, 2019). Bu çalışma kapsamında, maksimum ve 
minimum değerlerin bir ölçek oluşturduğu ve bu değerlerin referans alınarak diğer değerlerin yerleştirildiği min - maks normalizasyonuyla ön işleme prosedürü yapılmaktadır (Le vd., 2019):

$$
x_{i j}^{*}=\frac{x_{i j}-\min _{i=1}^{k} x_{i j}}{\operatorname{maks}_{i=1}^{k} x_{i j}-\min _{i=1}^{k} x_{i j}} j=1,2, \ldots, p .
$$

Yukarıdaki dönüşüm kullanılarak, $X=\left(x_{1} \ldots x_{p}\right)_{k \times p}$ veri matrisin normalize edilmiş hali $X^{*}=\left(x_{1}^{*} \ldots x_{p}^{*}\right)_{k \times p}$ veri matrisi ile ifade edilebilmektedir. Bu veri matrisinde $x_{i j}^{*}$ terimi, $i$. birimin ve $j$. normalize edilmiş değişkene göre almış olduğu değeri ifade etmektedir, dolayısıyla $x_{m}^{*}=\left(x_{1 m}^{*} \ldots x_{k m}^{*}\right)^{T}, m=1,2, \ldots, p$ 'dir. Klasik TBA'da olduğu gibi dirençli TBA'da da değişkenler arasındaki karşılıklı ilişkiler belirlenirken, eğer değişkenler aynı ölçü birimlerine sahipse kovaryans matrisinin, farklı ölçü birimlerine sahipse korelasyon matrisinin kullanılması gerekmektedir (Zou vd., 2006). $X$ veri matrisinin korelasyon matrisi $R$ ile gösterilsin. Korelasyon matrisinin özdeğerleri $\lambda_{1} \geq \lambda_{2} \geq \cdots \geq \lambda_{p}$ olmak üzere, bu özdeğerlere karşıllk gelen özvektörler ise $l_{1}, l_{2}, \ldots, l_{p}$ olsun. Değişkenlere ilişkin temel bileşenler (2) eşitliği sayesinde hesaplanmaktadır (Johnson ve Wichern, 2007: 437):

$$
P C_{m}=\sum_{j=1}^{p} l_{m j} x_{i j}^{*}, \quad m=1,2, \ldots, p \text { ve } i=1,2, \ldots, k .
$$

Yukarıdaki ifade edilenler kapsamında dirençli TBA'nın adımları aşağıda verilmektedir (Ngai ve Cheng 1997; Azadeh vd., 2007):

Adım 1. Veri ön işleme prosedürü gerçekleştirilir.

Adım 2. Örnekleme ilişkin $R$ korelasyon matrisi hesaplanmaktadır.

Adım 3. $\left|R-\lambda I_{p}\right|=0$ denklemi çözülerek kullanılarak $R$ korelasyon matrisinin özdeğerleri ve özvektörleri hesaplanmaktadır. Bu eşitlikteki $I_{p}, p \times p$ boyutlu birim matrisi ifade etmektedir. Korelasyon matrisinin $p$ tane özdeğeri $\hat{\lambda}_{1} \geq \hat{\lambda}_{2} \geq \cdots \geq \hat{\lambda}_{p}$ ve bu özdeğerlere karşılık gelen $p$ tane özvektör $\hat{t}_{1}, \hat{t}_{2}, \ldots, \hat{t}_{p}$ bulunmaktadır. Diğer taraftan $\sum_{j=1}^{p} \hat{\lambda}_{j}=p^{\prime}$ dir.

Adım 3. $P C_{j}=\sqrt{\hat{\lambda}_{j}} \hat{I}_{j},(j=1,2, \ldots, p)$ eşitliği kullanılarak temel bileşenler hesaplanmaktadır.

Adım 4. $\frac{\sum_{j=1}^{m} \widehat{\lambda}_{j}}{p} \geq 0.90$ eşitsizliğini sağlayan ilk $m$ temel bileşen seçilmektedir.

Adım 5. Dirençli $T B A_{i}=\sum_{j=1}^{m} w_{j} P C_{j}(i=1,2, \ldots, k)$ eşitliği kullanılarak seçilen $m$ temel bileşendeki yüklemelerin $w_{j}$ ağırlıkları ile ağırlıklandırılmış olduğu 


$$
\begin{array}{ll}
\text { doğrusal } & \text { bir } \quad \text { kombinasyonu }
\end{array}
$$

Adım 6. $k$ sayıdaki Dirençli $T B A_{i}(i=1,2, \ldots, k)$ skor değerlerine göre siralanmaktadir.

\section{B- Araştırmanın Veri Seti}

Çalışmaya konu olan Türkiye'deki İBBS-2 düzeyindeki 26 bölge, TÜİK tarafından yapılan istatistiki bölge birimleri sınıflaması sonucunda oluşturulmuştur. Bu bölgeler kodları ve içerdikleri iller bakımından Tablo 1'de sunulmaktadır.

Tablo 1. IBBSS-2 Düzeyindeki Bölgeler ve Bölgelerin İçerdikleri İller

\begin{tabular}{llll}
\hline Bölge & İler & Bölge & Iller \\
\hline TR10 & İstanbul & TR71 & Kırıkkale, Aksaray, Niğde, Nevşehir, Kırşehir \\
TR21 & Tekirdağ, Edirne, Kırklareli & TR72 & Kayseri, Sivas, Yozgat \\
TR22 & Balıkesir, Çanakkale & TR81 & Zonguldak, Karabük, Bartın \\
TR31 & İzmir & TR82 & Kastamonu, Çankırı, Sinop \\
TR32 & Aydın, Denizli, Muğla & TR83 & Samsun, Tokat, Çorum, Amasya \\
TR33 & Manisa, Afyon, Kütahya, Uşak & TR90 & Trabzon, Ördu, Giresun, Rize, Artvin, \\
TR41 & Bursa, Eskişehir, Bilecik & TRA1 Erzurum, Erzincan, Bayburt \\
TR42 & Kocaeli, Sakarya, Düzce, Bolu, Yalova & TRA2 & Ağrı, Kars, Iğdır, Ardahan \\
TR51 & Ankara & TRB1 & Malatya, Elazı̆̆, Bingöl, Tunceli \\
TR52 & Konya, Karaman & TRB2 & Van, Muş, Bitlis, Hakkâri \\
TR61 & Antalya, Isparta, Burdur & TRC1 & Gaziantep, Adıyaman, Kilis \\
TR62 & Adana, Mersin & TRC2 & Şanlıurfa, Diyarbakır \\
TR63 & Hatay, Kahramanmaraş, Osmaniye & TRC3 & Mardin, Batman, Şırnak, Siirt \\
\hline & & \\
\hline
\end{tabular}

Bölgesel kalkınma perspektifinden Tablo 1'de verilen bölgelerin işgücü hareketliliğinin değerlendirilmesinde, dirençli TBA'da kullanmak üzere altı değişken seçilmiştir. $X_{1}$ 'den $X_{6}$ 'ya kadar kodlanmış olan bu değişkenler, açıklamaları, birimleri ve kaynaklarıyla birlikte detaylı olarak Tablo 2'de sunulmaktadır. Diğer taraftan bölgelerin ilgili değişkenlere ilişkin 2014, 2015, 2016, 2017 ve 2018 yıllarına ait verileri TÜİK'den derlenerek analizde kullanılmıştır.

Tablo 2. Dirençli TBA'da Kullanılan Değişkenler

\begin{tabular}{llll}
\hline $\begin{array}{l}\text { Değişken } \\
\text { Kodu }\end{array}$ & Açıklama & Birim & Kaynak \\
\hline$X_{1}$ & İstihdam & Bin kişi & TÜIKK \\
$X_{2}$ & İşücü & Bin kişi & TÜİK \\
$X_{3}$ & İşücüne katılım oranı & $\%$ & TÜíK \\
$X_{4}$ & İşsizlik oranı & $\%$ & TÜíK \\
$X_{5}$ & Kişi başına gayri safi yurtiçi hâsıla (GSYH) & ABD Doları & TÜİK \\
$X_{6}$ & Net göç & Kişi & TÜİK \\
\hline \hline
\end{tabular}


Tablo 2'de verilen değişkenlerin tanımlamaları TÜİK tarafından şu şekilde yapılmıştır. İstihdam; İşbaşında olanlar ve işbaşında olmayanlar grubuna dâhil olan kurumsal olmayan çalışma çağındaki tüm nüfus istihdam edilen nüfustur. İşü̈cü; İstihdam edilenler ile işsizlerin oluşturduğu tüm nüfusu kapsar. İşgücüne katılım oranı; İşgücünün kurumsal olmayan çalışma çağındaki nüfus içindeki oranıdır. İşsizlik oranı; İşsiz nüfusun işgücü içindeki oranıdır. Kişi başına GSYH; GSYH, bir ülkedeki belirli bir dönemde üretilen mal ve hizmetlerden dolayı oluşan katma değere ilişkin standart bir ölçüdür. Net göç; Belirli bir alanın aldığ1 göç ile verdiği göç arasındaki farktır. Belirli bir alanın aldığ1 göç verdiğinden fazla ise net göç pozitif, verdiği göç aldığı göçten fazla ise net göç negatiftir.

İşgücü hareketliliğini temsil eden yukarıdaki değişkenler, bir sistem içerisindeki yakın ekonomik bağları olan bölgelerdeki ekonomik kalkınmanın sağlanmasında, alan yazında sıklıkla kullanılmaktadır (Razin ve Yuen, 1997; Lu, 2009; Cam ve Atan, 2018). Nitekim bölgeler arasındaki gelir düzeylerinin eşitlenmesinde işgücü hareketliliğini temsil eden istihdam, işsizlik oranı, GSYH ve net göç gibi değişkenlerin önemi oldukça büyüktür. Bu nedenle yıllara göre bölgelerin işgücü hareketliliğini değerlendiren bu çalışmada, nüfus demografi kuramı çerçevesinde net göç değişkeni üzerinden temel işgücü hareketliliği değerlendirilmiştir. Dirençli temel bileşenler analizinde ilk amaç boyut indirgemektir. Bölgeler arasında işgücü piyasasına ait temel değişkenleri belirlemektir. Daha sonra belirlenen bu değişkenlerin oluşturduğu bileşen skor değerlerine göre bölgeleri sıralamak ise ikinci amaç olarak kullanılmıştır.

\section{IV-AMPIRIKK BULGULAR}

İBBS-2 bölgelerine ait değişkenlerin normal dağılımı uygunluğunu belirlemek için 2014 2018 dönemlerine ait tek örneklem Kolmogorov - Smirnov (K-S) test sonuçları Tablo 3'de sunulmaktadır.

Tablo 3. Kolmogorov - Smirnov (K-S) Test Sonuçlart ${ }^{1}$

\begin{tabular}{|c|c|c|c|c|c|}
\hline Değişken & $\begin{array}{l}2014 \\
\text { (K-S ist / } \\
\text { P değ.) }\end{array}$ & $\begin{array}{l}2015 \\
\text { (K-S ist / } \\
\text { P değ.) }\end{array}$ & $\begin{array}{l}2016 \\
\text { (K-S ist / } \\
\text { P değ.) }\end{array}$ & $\begin{array}{l}2017 \\
\text { (K-S ist / } \\
\text { P değ.) }\end{array}$ & $\begin{array}{l}2018 \\
\text { (K-S ist / } \\
\text { P değ.) }\end{array}$ \\
\hline İstihdam & $\begin{array}{l}0,243 \\
(0,000)\end{array}$ & $\begin{array}{l}0,248 \\
(0,000)\end{array}$ & $\begin{array}{l}0,255 \\
(0,000)\end{array}$ & $\begin{array}{l}0,245 \\
(0,000)\end{array}$ & $\begin{array}{l}0,237 \\
(0,001)\end{array}$ \\
\hline İşgücü & $\begin{array}{l}0,258 \\
(0,000)\end{array}$ & $\begin{array}{l}0,260 \\
(0,000)\end{array}$ & $\begin{array}{l}0,268 \\
(0,000)\end{array}$ & $\begin{array}{l}0,256 \\
(0,000)\end{array}$ & $\begin{array}{l}0,251 \\
(0,000)\end{array}$ \\
\hline İşsizlik oranı & $\begin{array}{l}0,199 \\
(0,009)\end{array}$ & $\begin{array}{l}0,219 \\
(0,002)\end{array}$ & $\begin{array}{l}0,249 \\
(0,002)\end{array}$ & $\begin{array}{l}0,192 \\
(0,008)\end{array}$ & $\begin{array}{l}0,194 \\
(0,008)\end{array}$ \\
\hline İşgücüne katılım oranı & $\begin{array}{l}0,194 \\
(0,002)\end{array}$ & $\begin{array}{l}0,194 \\
(0,061)\end{array}$ & $\begin{array}{l}0,218 \\
(0,002)\end{array}$ & $\begin{array}{l}0,192 \\
(0,004)\end{array}$ & $\begin{array}{l}0,195 \\
(0,003)\end{array}$ \\
\hline Kişi başına GSYH & $\begin{array}{l}0,160 \\
(0,008)\end{array}$ & $\begin{array}{l}0,196 \\
(0,066)\end{array}$ & $\begin{array}{l}0,195 \\
(0,006)\end{array}$ & $\begin{array}{l}0,195 \\
(0,006)\end{array}$ & $\begin{array}{l}0,188 \\
(0,009)\end{array}$ \\
\hline Bölgelerarası net göç & $\begin{array}{l}0,211 \\
(0,004)\end{array}$ & $\begin{array}{l}0,207 \\
(0,006)\end{array}$ & $\begin{array}{l}0,194 \\
(0,004)\end{array}$ & $\begin{array}{l}0,218 \\
(0,003)\end{array}$ & $\begin{array}{l}0,232 \\
(0,001)\end{array}$ \\
\hline
\end{tabular}

Tablo 3’e göre 2014 - 2018 yılları arasında tüm değişkenler için P değerleri $<\alpha=0,05$ olduğu için değişkenler normal dağılmamıştır sonucuna ulaşılmaktadır. Genellikle TR10, TR31, TR41, TR42 ve TR51 pozitif yönlü (highest) uç değer olan bölgeler iken TRA1, TRA2, TRC3, TR81 ve TR82 ise negatif yönlü (lowest) uç değer olan bölgelerdir. Değişkenler normal dağılım göstermediği ve büyük illerin yer aldığı bölgeler ile küçük illerin yer aldığı bölgelerde değişkenlerin uç değerlere dönüşmesi söz konusu olduğu için klasik temel

1 Parantez içerisinde verilenler, test istatistiğin $\% 5$ düzeyinde anlamlılık değerlerini ifade etmektedir. 
bileşenler yerine teorik bölümde açıklanan dirençli temel bileşenler yaklaşımı tercih edilmiştir.

Tablo 4'de tüm değişkenler için 2014 - 2018 dönemlerine ait en küçük değer, en büyük değer, ortalama ve standart sapmadan oluşan temel istatistik değerleri verilmiş̧tir.

Tablo 4. Değişkenlerin Temel İstatistik Değerleri (2014 - 2018)

\begin{tabular}{|c|c|c|c|c|c|c|}
\hline Değişken & & 2014 & 2015 & 2016 & 2017 & 2018 \\
\hline \multirow{4}{*}{ İstihdam } & En küçük & 292 & 290 & 318 & 330 & 327 \\
\hline & En büyük & 5096 & 5306 & 5558 & 5664 & 5899 \\
\hline & Ortalama & 997,38 & 1023,77 & 1046,19 & 1084,27 & 1105,23 \\
\hline & Std. Hata & 181,04 & 188,35 & 197,78 & 201,55 & 210,45 \\
\hline \multirow{4}{*}{ İşgücü } & En küçük & 312 & 311 & 338 & 346 & 344 \\
\hline & En büyük & 5785 & 6092 & 6427 & 6578 & 6738 \\
\hline & Ortalama & 1107,04 & 1141,42 & 1174,46 & 1217,04 & 1241,38 \\
\hline & Std. Hata & 205,88 & 216,60 & 228,92 & 234,45 & 240,13 \\
\hline \multirow{4}{*}{ İşsizlik oranı } & En küçük & 3 & 4 & 5 & 4 & 5 \\
\hline & En büyük & 24 & 25 & 28 & 27 & 25 \\
\hline & Ortalama & 9,28 & 9,50 & 10,13 & 9,98 & 10,53 \\
\hline & Std. Hata & 0,90 & 0,92 & 1,00 & 0,94 & 0,99 \\
\hline \multirow{4}{*}{ İşgücüne katılım oranı } & En küçük & 37 & 38 & 39 & 39 & 41 \\
\hline & En büyük & 56 & 57 & 58 & 59 & 60 \\
\hline & Ortalama & 49,92 & 50,51 & 50,89 & 51,59 & 51,97 \\
\hline & Std. Hata & 0,90 & 0,90 & 0,90 & 0,83 & 0,83 \\
\hline \multirow{4}{*}{ Kişi başına GSYH } & En küçük & 4959 & 4324 & 4422 & 4177 & 3780 \\
\hline & En büyük & 19957 & 18343 & 18169 & 17870 & 16264 \\
\hline & Ortalama & 9994,27 & 9050,58 & 8924,69 & 8672,31 & 7924,12 \\
\hline & Std. Hata & 744,96 & 667,44 & 655,02 & 646,67 & 598,17 \\
\hline \multirow{4}{*}{ Bölgelerarası net göç } & En küçük & -37192 & -40304 & -71307 & -33489 & -210321 \\
\hline & En büyük & 40009 & 51047 & 45323 & 44858 & 81795 \\
\hline & Ortalama & 0,00 & 0,00 & 0,00 & 0,00 & 0,00 \\
\hline & Std. Hata & 4241,04 & 4985,21 & 5147,41 & 4005,28 & 9625,85 \\
\hline
\end{tabular}

Bu aşamada Tablo 5'de 2014 - 2018 yılları arasında yapılan dirençli TBA'nın birden büyük değer alan özdeğerleri ve toplam varyansı açıklama yüzdeleri verilmiştir.

Tablo 5. Dirençli Temel Bileşenler Analizi Özdeğerler ve Toplam Varyansı Açıklama Yüzdeleri (2014 - 2018)

\begin{tabular}{ccccc}
\hline Dönem & Birinci Özdeğer & İkinci Özdeğer & Üçüncü Özdeğer & $\begin{array}{c}\text { Toplam Varyans1 } \\
\text { Açılama Yüzdesi }\end{array}$ \\
\hline $\mathbf{2 0 1 4}$ & 3,316 & 1,658 & - & 82,908 \\
$\mathbf{2 0 1 5}$ & 3,640 & 1,623 & - & 87,725 \\
$\mathbf{2 0 1 6}$ & 2,973 & 2,008 & - & 83,015 \\
$\mathbf{2 0 1 7}$ & 3,259 & 1,520 & 1,006 & 96,424 \\
$\mathbf{2 0 1 8}$ & 3,539 & 1,699 & - & 87,302 \\
\hline
\end{tabular}


Tablo 5'de verilen değerler incelendiğinde; sadece 2017 y1lında üç temel bileşen olduğunu diğer dönemlerde ise iki temel bileşenin özdeğerinin birden büyük olduğu görülmektedir. Toplam varyansdaki değişim tüm dönemler için yüzde seksenin üzerindedir. Tablo 6'da 2014 - 2018 yılları arasında yapılan dirençli TBA'nın faktör yükleri ve döndürülmüş bileşen matris değerleri verilmiştir.

Tablo 6. Dirençli Temel Bileşenler Analizi Faktör Yükleri ve Döndürülmüş Bileşen Matrisi Değerleri (2014 - 2018)

\begin{tabular}{|c|c|c|c|}
\hline Dönem & Birinci Özdeğer & İkinci Özdeğer & Üçüncü Özdeğer \\
\hline \multirow{4}{*}{2014} & İstihdam $[0,944]$ & & \multirow{4}{*}{-} \\
\hline & İşgücü [0,944] & İşsizlik oranı $[-0,879]$ & \\
\hline & Kişi başına GSYH $[0,902]$ & \multirow[t]{2}{*}{ İşgücüne katılım oran 10,865$]$} & \\
\hline & Bölgelerarası net göç $[0,648]$ & & \\
\hline \multirow{4}{*}{2015} & İstihdam $[0,940]$ & & \multirow{4}{*}{ - } \\
\hline & İşgücü $[0,939]$ & İşsizlik oranı $[-0,904]$ & \\
\hline & Kişi başına GSYH $[0,924]$ & İşgücüne katılım oranı $[0,857]$ & \\
\hline & Bölgelerarası net göç $[0,837]$ & & \\
\hline \multirow{3}{*}{2016} & İstihdam $[0,975]$ & İşsizlik oran1 $[-0,762]$ & \\
\hline & İşgücü $[0,972]$ & İşgücüne katılım oranı $[0,767]$ & \\
\hline & Kişi başına GSYH Değer $[0,876]$ & Bölgelerarası net göç $[0,831]$ & \\
\hline \multirow{3}{*}{2017} & İstihdam $[0,992]$ & \multirow{3}{*}{ Bölgelerarası net göç $[0,990]$} & İşsizlik oran1 $[0,951]$ \\
\hline & İşgücü $[0,992]$ & & İşgücüne katılım oranı \\
\hline & Kişi başına GSYH $[0,704]$ & & {$[-0,761]$} \\
\hline \multirow{4}{*}{2018} & İstihdam $[0,980]$ & & \multirow{4}{*}{ - } \\
\hline & İşgücü $[0,984]$ & İssizlik oranı $[-0,862]$ & \\
\hline & Kişi başına GSYH $[0,754]$ & \multirow{2}{*}{ İşgücüne katılım oranı $[0,867]$} & \\
\hline & Bölgelerarası net göç $[-0,891]$ & & \\
\hline
\end{tabular}

Tablo 6'da verilen değerler incelendiğinde; birinci temel bileşen içinde faktör yüklerine göre çoğunlukla en önemli değişken istihdam (bin kişi) olmuştur. Bunu işgücü (bin kişi) ve kişi başına GSYH değer (2009 Bazlı) ABD doları cari fiyatlarla değişkeni ve kısmen olmak üzere bölgelerarası net göç değişkenleridir. İkinci temel bileşende ise faktör yüklerine göre çoğunlukla en önemli değişken işsizlik oranı olmuştur. Bunu işgücüne katılım oranı ve kısmen bölgeler arası net göç değişkenleri izlemektedir.

İBBS-2 bölgelerinin işgücü hareketliliklerinin yıllara göre değerlendirilmesinde dirençli TBA'nın kullanılması sonucunda elde edilen sonuçlar Tablo 7'de sunulmaktadır. 
Tablo 7. Dirençli Temel Bileşenler Analizine İlişkin Sonuçlar ${ }^{2}$

\begin{tabular}{|c|c|c|c|c|c|}
\hline Bölge & 2014 & 2015 & 2016 & 2017 & 2018 \\
\hline TR10 & $14,399(1)$ & 15,609 (1) & $7,608(1)$ & $11,805(1)$ & $13,198(1)$ \\
\hline TR21 & 0,048 (9) & 0,108 (9) & 3,752 (4) & 1,221 (8) & 3,259 (3) \\
\hline TR22 & $-0,813(12)$ & $-1,765$ (19) & $-0,141(14)$ & $-1,107(15)$ & $-0,678(15)$ \\
\hline TR31 & 3,756 (3) & 3,813 (3) & 3,249 (5) & $4,566(4)$ & 2,819 (5) \\
\hline TR32 & $0,908(7)$ & $0,270(7)$ & $2,178(9)$ & 0,519 (9) & $2,346(6)$ \\
\hline TR33 & $-0,988(15)$ & $-0,885(12)$ & $1,381(10)$ & $-0,880(13)$ & 1,446 (9) \\
\hline TR41 & $1,878(5)$ & 2,268 (5) & 2,349 (7) & $3,470(5)$ & 2,253 (7) \\
\hline TR42 & 3,067 (4) & 3,596 (4) & $4,042(3)$ & 4,909 (3) & $3,200(4)$ \\
\hline TR51 & 5,185 (2) & $5,548(2)$ & $4,047(2)$ & 5,459 (2) & 3,632 (2) \\
\hline TR52 & $-1,312(17)$ & $-1,230(14)$ & 0,014 (13) & $-1,922(18)$ & $-0,052(13)$ \\
\hline TR61 & $1,266(6)$ & $1,624(6)$ & 2,318 (8) & $1,931(7)$ & $1,810(8)$ \\
\hline TR62 & 0,472 (8) & $0,122(8)$ & $-0,362(15)$ & $-0,316(11)$ & $-0,411(14)$ \\
\hline TR63 & $-0,211(10)$ & $-0,199(10)$ & $-3,070(22)$ & $-0,971(14)$ & $-2,195(20)$ \\
\hline TR71 & $-2,418(21)$ & $-1,803(20)$ & $-0,941(18)$ & $-1,215(16)$ & $-1,623(17)$ \\
\hline TR72 & $-0,934(14)$ & $-1,274(16)$ & $-0,803(17)$ & $-0,657(12)$ & $-2,601(22)$ \\
\hline TR81 & $-2,814(23)$ & $-2,560(22)$ & $-0,798(16)$ & $-2,440(20)$ & $-1,643(18)$ \\
\hline TR82 & $-3,079(25)$ & $-2,808(23)$ & $1,276(11)$ & $-3,327(23)$ & $0,254(12)$ \\
\hline TR83 & $-1,573(19)$ & $-1,675$ (17) & 0,149 (12) & $-1,992(19)$ & 0,899 (10) \\
\hline TR90 & $-1,191(16)$ & $-1,764(18)$ & $2,569(6)$ & $-4,111(24)$ & 0,447 (11) \\
\hline TRA1 & $-2,961(24)$ & $-3,458(24)$ & $-1,049(19)$ & $-4,158(25)$ & $-2,394(21)$ \\
\hline TRA2 & $-4,849(26)$ & $-4,848(26)$ & $-2,126(21)$ & $-5,259(26)$ & $-2,013(19)$ \\
\hline TRB1 & $-2,382(20)$ & $-2,314(21)$ & $-1,808(20)$ & $-2,594(21)$ & $-1,162(16)$ \\
\hline TRB2 & $-2,656(22)$ & $-3,612(25)$ & $-5,786(25)$ & $-3,316(22)$ & $-5,279(25)$ \\
\hline TRC1 & $-1,561(18)$ & $-1,239(15)$ & $-3,502(23)$ & $-0,103(10)$ & $-2,898(23)$ \\
\hline TRC2 & $-0,899(13)$ & $-1,024(13)$ & $-5,201(24)$ & $-1,711(17)$ & $-4,368(24)$ \\
\hline TRC3 & $-0,341(11)$ & $-0,498(11)$ & $-9,345(26)$ & $2,200(6)$ & $-8,246(26)$ \\
\hline
\end{tabular}

Tablo 7'de verilen temel bileşen değerlerinde Tablo 5'de verilen özdeğerler ağırlık olarak kullanılmıştır. Aşağıda ilk aşamada 2018 yılı için birinci ve ikinci temel bileşen skor değerleri için kullanılan tahmin denklemi ve parametreleri verilmiştir. Bu denklem eşitlikleri ile ilgili bölgenin ham verileri çarpılıp toplanarak her bir bileşen için bölgenin aldığı temel bileşen

\footnotetext{
${ }^{2}$ Parantez içerisinde verilenler, bölgelerin ilgili yıldaki analiz sonucuna göre almış oldukları sıra değerlerini ifade etmektedir.
} 
skor değerine ulaşılmaktadır. Daha sonra ise toplam temel bileşen skor değerleri için kullanılan formülasyon Eşitlik (3) olarak tanımlanmıştır.

Birinci Temel Bileşen Skoru $=0,287 *$ İstihdam (bin kişi) $+0,291 *$ İşgücü (bin kişi) $+0,122 *$ İşsizlik oranı $+0,026 *$ İşgücüne katılım oranı $+0,192 *$ Kişi başına GSYH Değer (2009 Bazlı) ABD Doları ve Cari Fiyatlarla - 0,289 * Bölgelerin Net Göç Bilgileri

İkinci Temel Bileşen Skoru = -0,001 * İstihdam (bin kişi) - 0,002 * İşgücü (bin kişi) $-0,504 *$ İşsizlik oranı $+0,470 *$ İşgücüne katılım oranı $+0,217 *$ Kişi başına GSYH Değer (2009 Bazlı) ABD Doları ve Cari Fiyatlarla + 0,214 * Bölgelerin Net Göç Bilgileri

Toplam Temel Bileşen Skor Değeri = Birinci Temel Bileşen Skoru * Birinci Özdeğer + İkinci Temel Bileşen Skoru * İkinci Özdeğer

Tablo 7’ye göre; 2014 - 2018 yılları arasında TR10 (İstanbul) ve TR51 (Ankara) bölgelerinin sırasıyla birinci ve ikinci sırada yer aldıkları ve yıllara göre bu bölgelerin sıralamalarının hiç değişmediği görülmektedir. Diğer taraftan yıllara göre performans sıralamalarının ortalaması alındığında, TRB2, TRA2 ve TRA1 bölgelerinin diğer bölgelere göre daha gerilerde yer aldığg söylenebilmektedir. İşgücü hareketliliğin değerlendirildiği bu çalışmada, bölgelerin yıllara göre almış oldukları sıralama değerleri görsel olarak Şekil 1'de sunulmaktadır. Şekil 1 'de çemberin içinde yer alan $0,5,10,15,20,25$ ve 30 değerleri bölgelerin ilgili yılda almış olduğu temel bileşen değerlerinin sıralamasıdır. İBBS- 2 bölgelerinin yıllara göre sıralamaları arasındaki korelasyon katsayıları ise Tablo 8'de sunulmaktadır.

Şekil 1. Yıllara Göre IBBBS-2 Bölgelerinin Almıs Oldukları Sıralamalar

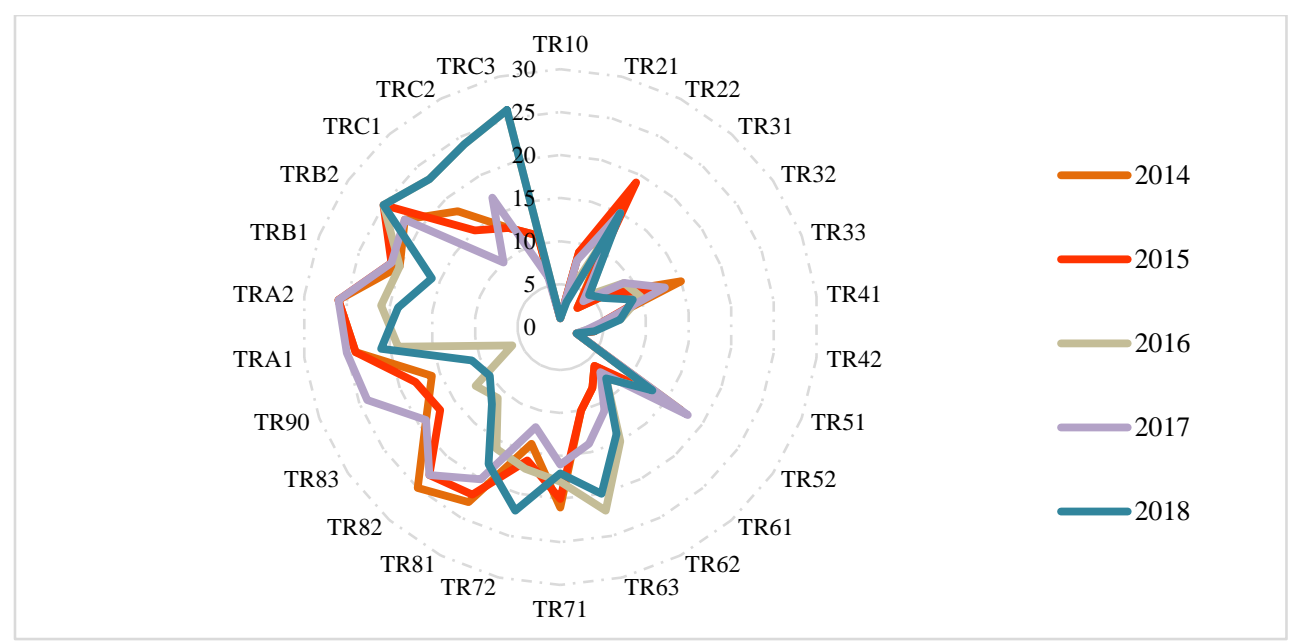

Şekil 1 ve Tablo 8'den hareketle, İBBS-2 düzeyindeki bölge sıralamalarının en çok örtüştüğü yılların 0,965 korelasyon katsayısı ile 2016 ve 2018 yılları olduğu söylenebilmektedir. 26 bölgenin yıllar itibari ile yer aldığı sıralama değerleri arasında istatistiksel olarak anlamlı sıra korelasyon değerleri bulunmuştur. Bu analiz sonuçlarının yıllar itibariyle karşılaştırılmasının yorumlanması açısından önemlidir. 
Tablo 8. Yıllara Göre Bölgelerin Sıralamaları Arasındaki Spearman Sıra Korelasyon Katsayıları

\begin{tabular}{cccccc}
\hline Yıllar & $\mathbf{2 0 1 4}$ & $\mathbf{2 0 1 5}$ & $\mathbf{2 0 1 6}$ & $\mathbf{2 0 1 7}$ & $\mathbf{2 0 1 8}$ \\
\hline $\mathbf{2 0 1 4}$ & 1,000 & $0,964^{*}$ & $0,616^{*}$ & $0,911^{*}$ & $0,631^{*}$ \\
$\mathbf{2 0 1 5}$ & $0,964^{*}$ & 1,000 & $0,631^{*}$ & $0,925^{*}$ & $0,664^{*}$ \\
$\mathbf{2 0 1 6}$ & $0,616^{*}$ & $0,631^{*}$ & 1,000 & $0,525^{*}$ & $0,965^{*}$ \\
$\mathbf{2 0 1 7}$ & $0,911^{*}$ & $0,925^{*}$ & $0,525^{*}$ & 1,000 & $0,549^{*}$ \\
$\mathbf{2 0 1 8}$ & $0,631^{*}$ & $0,664^{*}$ & $0,965^{*}$ & $0,549^{*}$ & 1,000 \\
\hline "Korelasyon katsayıs1 $\alpha=0,01$ düzeyinde istatistiksel olarak anlamlidır. & & \\
\hline \hline
\end{tabular}

Yıllara göre bölgelerin işgücü hareketliliklerini karşılaştırmalı olarak inceleyen bu analiz sayesinde, sosyo-ekonomik açıdan gelişmiş illeri kapsayan bölgelerin performans sıralamasında üstlerde, sosyo - ekonomik açıdan orta derece gelişmiş ya da nispeten gelişmede geride kalmış bölgelerin de performans sıralamasında altlarda yer aldıkları söylenebilmektedir.

\section{SONUÇ}

Bölgesel kalkınma politikaları süreç içerisinde gelişmiş ya da gelişmekte olan ülke ayrımı gözetmeksizin her ülke için ortak bir problem olmuş ve bu problem için her ülke kendi ekonomik şartları çerçevesinde birtakım politikalar geliştirmiştir. Çünkü bölgesel kalkınma, sürdürülebilir büyümenin sağlanması, sosyokültürel yapının gelişmesi ve toplumsal adaletin sağlanması açısından oldukça önemlidir. Bu nedenle bölgelerarası farklılıkların giderilmesi son derece önemlidir. Bölgesel kalkınmanın sağlanması şüphesiz ki birçok faktöre bağlıdır. $\mathrm{Bu}$ faktörlerin en önemlilerinden bir tanesi geri kalmış bölgelerdeki işgücü piyasasında daha etkin bir yapı oluşturulması gerekliliğidir. Bu nedenle bölgelerdeki mevcut işgücü yapısının detaylı bir analizinin oldukça önemlidir.

Bölgesel kalkınma hedefleri çerçevesinde konulan hedeflere ulaşmak için, dar anlamda iller geniş anlamda bölgeler bazında maksimum seviyede bir refah artışının yakalanması gerekmektedir. $\mathrm{Bu}$ durumun başarılmasında işgücü piyasaları kritik bir öneme sahip olduğundan güçlü, istikrarlı ve verimli bir işgücü piyasası oluşturulmalıdır. Güçlü işgücü piyasası şartlarının oluşturulduğu bölgelere bakıldığında bu bölgelerin gelişmiş bölgeler olduğu, güçlü işgücü piyasası şartlarının oluşturulamadığ 1 bölgelere bakıldığında ise bu bölgelerin daha çok geri kalmış bölgeler olarak karşımıza çıktığı görülmektedir. Buradan hareketle üzerinde durulması gereken öncelikli konuların başında işsizlik probleminin çözülerek, istihdam sorununa çözüm üretilmesi gelmektedir. Söz konusu hedefe ulaşılamadığı takdirde güçlü bir işgücü piyasası şartlarının oluşturulması mümkün olmayacaktır. Diğer taraftan özellikle genç ve çalışma çağında olan nüfusun sisteme dâhil edilmesi, eğitim seviyesi yüksek nitelikli bir işgücü yapının kurulmasını, göç hareketlerinin kontrol altına alınması ve kadın istihdamının artırılması bu noktada üzerinde durulması gereken diğer konuları oluşturmaktadır.

Yukarıda anlatılanlar ışı̆̆ında çalışmada, bölgelerin işgücü hareketliliğinin yıllara göre geçirdikleri değişimler karşılaştırmalı olarak tespit edilmeye çalışılmaktadır. Bu amaçla çalışmada, çok değişkenli istatistiksel analizlerden olan dirençli TBA kullanılmıştır. Dirençli TBA sayesinde, bölgelerin işgücü hareketliliğini karakterize eden ve aralarında ilişki olan istihdam, işsizlik oranı, GSYH ve göç gibi değişkenler, aralarında ilişki olmayan daha az sayıdaki yeni bileşenlere dönüştürülmüştür. $\mathrm{Bu}$ daha az sayıdaki yeni bileşenler ile değişkenlerdeki toplam varyans büyük bir oranda açıklanmaya çalışılmıştır. Aynı zamanda 2014 - 2018 yılları arasındaki her bir yıl için İBBS-2 bölgelerine ilişkin tekrarlanmış olan 
dirençli TBA sayesinde, bölgelerin yıllara göre karşılaştırmalı olarak değerlendirilmesi de mümkün kılınmaktadır.

Çalışma sonucunda elde edilen bulgular neticesinde, hangi bölgelerin hangi yıllarda nasıl bir performans gösterdiğinin tespit edilmesi mümkün olmaktadır. Buna göre İstanbul, Ankara, İzmir gibi sosyo-ekonomik açıdan gelişmiş illeri kapsayan bölgelerin, dirençli TBA performans sıralamasında da üst sıralarda yer aldıkları görülmektedir. Diğer taraftan Doğu ve Güneydoğu Anadolu'da yer alan illeri kapsayan bölgelerin ise dirençli TBA performans sıralamasında daha alt sıralarda yer aldıkları görülmektedir. Türkiye'nin İBBS-2 düzeyindeki 26 bölgesi için yapılan bu analizin, sonraki çalışmalarda işgücü hareketliliğini temsil eden daha çok sayıdaki değişken ile birlikte daha geniş bir zaman aralığı için yapılması planlanmaktadır.

\section{Kaynakça}

Akın, N. (2006). Bölgesel Kalkınma Araçları ile Kalkınma Ajanslarının Uyum, İşbirliği ve Koordinasyonu. TEPAV Bölgesel Kalkınma ve Bölgesel Yönetissim Seтроzyuтu. 295-304.

Azadeh, A., Ghaderi, S. F. ve Ebrahimipour, V. (2007). An Integrated PCA DEA Framework for Assessment and Ranking of Manufacturing Systems Based on Equipment Performance. Engineering Computations. 24(4). 347-372.

Berber, M. ve Çelepçi, E. (2005). Türk Bölgesel Kalkınma Politikalarında Yeni Arayışlar: Kalkınma Ajansları ve Türkiye'de Uygulanabilirliği. Doğu Karadeniz Bölgesel Kalkınта Sempozyumu. 13-14.

Bozdoğan, M. (2014). Bölgesel Kalkınma ve İBBS Esasına Dayanan Yeni Yatırım Teşvik Sisteminin Uygulama Sonuçlarının Değerlendirilmesi. Türkiye'de Bölgesel Kalkınma ve Teşvik Politikaları (Editör: Mine Nur Bozdoğan). Ankara: Nobel Yayıncılık.

Cam, E. ve Atan, M. (2018). Türkiye'de İl Bazında İstihdam Politikalarının Etkinliği. Bilgi. 20(1). 102-123.

Campbell, N. A. (1980). Robust Procedures in Multivariate Analysis I: Robust Covariance Estimation. Journal of the Royal Statistical Society: Series C (Applied Statistics). 29(3). 231-237.

Candès, E. J., Li, X., Ma, Y. ve Wright, J. (2011). Robust Principal Component Analysis? Journal of the Association for Computing Machinery. 58(3). 1-37.

Cankorkmaz, Z. (2011). Türkiye’de Bölgesel Kalkınma Ajansları ve Bu Ajanslara Yönelik Eleştiriler. Dokuz Eylül Üniversitesi İktisadi ve İdari Bilimler Fakültesi Dergisi. 26. 113-138.
Cerev, G. ve Yenihan, B. (2017). İşücü Piyasası Temel Kavramları Doğrultusunda Elazı̆̆ İli İşgücü Piyasasının Mevcut Durumu ve Analizi. Firat Üniversitesi Harput Araşstırmaları Dergisi. 4(1).77-90.

Croux, C. ve Haesbroeck, G. (2000). Principal Component Analysis Based on Robust Estimators of the Covariance or Correlation Matrix: Influence Functions and Efficiencies. Biometrika. 87(3). 603-618.

Croux, C. ve Ruiz-Gazen, A. (2005). High Breakdown Estimators for Principal Components: The Projection-Pursuit Approach Revisited. Journal of Multivariate Analysis. 95(1). 206-226.

De la Torre, F. ve Black, M. J. (2001, July). Robust Principal Component Analysis for Computer Vision. In Proceedings Eighth IEEE International Conference on Computer Vision. ICCV 2001. 362-369.

Feng, J., Xu, H. ve Yan, S. (2013). Online Robust PCA via Stochastic Optimization. In Advances in Neural Information Processing Systems. 404-412.

Gündoğan, N. ve Biçerli, M. K. (2003). Çalışma Ekonomisi. Eskişehir: AÜ Yayınları.

Hasanoğlu, M. ve Aliyev, Z. (2006). Avrupa Birliği ile Bütünleşme Sürecinde Türkiye'de Bölgesel Kalkınma Ajansları. Sayıştay Dergisi. 60. 81-103.

Huber, P. J. ve Ronchetti, E. (1981). Robust Statistics. New York: John Wiley \& Sons.

Işı̆̆ıçok, E. (2011). İstihdam ve İşsizlik. Bursa: Ekin Kitabevi. 
Johnson R. A. ve Wichern D. W. (2007). Multivariate Statistical Analysis (6.th Edition). Upper Saddle River, New Jersey: Pearson Prentice Hall.

Keleş, R. (2000). Kentleşme Politikası. Ankara: İmge Kitabevi.

Le, T. H., Chang, Y., Taghizadeh-Hesary, F. ve Yoshino, N. (2019). Energy Insecurity in Asia: A Multi-Dimensional Analysis. Economic Modelling. 83. 84-95.

Li, G. ve Chen, Z. (1985). Projection-Pursuit Approach to Robust Dispersion Matrices and Principal Components: Primary Theory and Monte Carlo. Journal of the American Statistical Association. 80(391). 759-766.

Lordoğlu, K., Özkaplan, N. ve Törüner, M. (1999). Çalı̧̧ma İktisadı. İstanbul: Beta Basım Yayın ve Dağıtım.

Lu, D. (2009). The Economic Consequence of Labor Mobility in China's Regional Development. Asian Economic Papers. 8(2). 85114.

Meyer, J. R. (1966). Bölgesel İktisat: Bir Araştırma, İktisadi Kalkınma Seçme Yazılar. Ankara: ODTÜ İdari İlimler Fakültesi Yayını.

Ngai, E. W. T. ve Cheng, T. C. E. (1997). Identifying Potential Barriers to Total Quality Management Using Principal Component Analysis and Correspondence Analysis. International Journal of Quality \& Reliability Management. 14(4). 391-408.

Özaslan, A. ve Ünlü, H. (2015). Türkiye’de Bölgesel Kalkınma Politikalarında Değişim ve Kalkınma Ajansları. Mehmet Akif Ersoy Üniversitesi Sosyal Bilimler Enstitüsü Dergisi. 13. 64-83.

Özdemir, V. (2014). Türkiye'de Planlı Kalkınma Deneyimleri. Marmara Üniversitesi [https://dumludag. files.wordpress.com /2013/09/ozdemir_planlama.pdf]. (Erişim: 06 Ağustos 2020).

Razin, A. ve Yuen, C. W. (1997). Factor Mobility and Income Growth: Two Convergence Hypotheses. Review of Development Economics. 1(2). 171-190.

Rösch, İ. A. (1992). Almanya'da Bölgesel Kalkınma Yaklaşımları. Ankara: DPT Kalkınmada Öncelikli Yöreler ve Bölgesel Kalkınma Genel Müdürlüğü Yayınları.
Sakal, M. ve Demirhan, H. (2014). Bölgesel Politikalar Eksenindeki Değişim Sürecinde Türkiye'de İzlenen Bölgesel Kalkınma Politikalarının Analizi. Türkiye'de Bölgesel Kalkınma ve Teșvik Politikaları (Editör: Mine Nur Bozdoğan). Ankara: Nobel Yayıncılık.

Sezgin, A. (2013). Kalkinma Ajansl Uygulamasının Gelişmiş ve Az Gelişmiş Ülke Örnekleri Açısından Sonuçları (Yüksek Lisans Tezi). Hitit Üniversitesi Sosyal Bilimler Enstitüsü. Çorum.

Singh, D. ve Singh, B. (2019). Investigating the Impact of Data Normalization on Classification Performance. Applied Soft Computing. 105524, doi: 10.1016/j.asoc.2019.105524.

Sivri, U., Ceylan, S. ve Artan, S. (2000). Bölgeleraras1 Gelir Farklılıkları ve Kuznets Hipotezi. 9. Ulusal Bölge Bilimi/Bölge Planlama Kongresi. KTÜ Basımevi. Trabzon.

Stanimirova, I., Walczak, B., Massart, D. L. ve Simeonov, V. (2004). A Comparison between Two Robust PCA Algorithms. Chemometrics and Intelligent Laboratory Systems. 71(1). 8395.

Şahinkaya, S. (2001). Bölgesel İktisadi Dengesizlikleri Giderme Çabaları/Politikaları Üzerinde Bazı Değerlendirmeler. Cevat Geray'a Armağan. Ankara: Mülkiyeliler Birliği Yayınlar1.

Takım, A. (2011). Türkiye'de 1960-1980 Yılları Arasında Uygulanan Kalkınma Planlarında Maliye Politikaları. Maliye Dergisi. 160. 154176.

Tansel, A. (2012). 2050'ye Doğru Nüfus, Bilim ve Yönetim: İsgǘcü Piyasasına Bakış. İstanbul: TÜSİAD.

Walras, L. (1953). Abrege des Elements d'Economie Politique Pure. Librairie Generale de Droit et de Jurisprudence. Paris.

Wright, J., Ganesh, A., Rao, S., Peng, Y. ve Ma, Y. (2009). Robust Principal Component Analysis: Exact Recovery of Corrupted LowRank Matrices via Convex Optimization. In Advances in Neural Information Processing Systems. 2080-2088.

Xu, H., Caramanis, C. ve Sanghavi, S. (2010). Robust PCA via Outlier Pursuit. In Advances in Neural Information Processing Systems. 24962504.

Zou, H., Hastie, T. ve Tibshirani, R. (2006). Sparse Principal Component Analysis. Journal of Computational and Graphical Statistics. 15(2). 265-286. 